\title{
De grote school van de natie. Legerartsen over drankmisbruik en geslachtsziekten in het Belgisch leger (circa 1850-1950) ${ }^{1}$
}

\section{LIESBET NYS}

De geschiedenis van het alcoholisme in de tweede helft van de negentiende en de eerste helft van de twintigste eeuw wordt, net als de geschiedenis van de geslachtsziekten in die periode, vaak in termen van moralisering en disciplinering beschreven. De strijd tegen het drankmisbruik en de venerische ziekten wordt geïnterpreteerd als een (al dan niet weloverwogen en bewuste) poging van de gevestigde klassen om hun restrictieve (seksuele) moraal aan de arbeidersklasse op te dringen, om middenklassewaarden als matigheid en zelfcontrole te verdedigen tegen de losbandigheid van het proletariaat $^{2}$. Het valt echter op dat bijvoorbeeld de strijd die in het leger tegen de geslachtsziekten werd gevoerd, veel minder vanuit dit moraliseringsperspectief wordt bekeken. Vaak wordt beweerd dat legerartsen in hun strijd tegen de venerische ziekten bij soldaten niet zozeer door morele als wel door sanitaire motieven werden gedreven, dat hun offensief tegen de geslachtsziekten vooral door een bekommernis om de volksgezondheid was ingegeven ${ }^{3}$.

Wat de Belgische legerartsen betreft, lijkt het inderdaad zo dat hun offensief tegen de geslachtsziekten in aanzienlijke mate door sanitaire motieven was geïnspireerd. In ieder geval hebben zij hun venerisch offensief vaak met sanitaire argumenten gelegitimeerd en een aantal onder hen stelde zelfs expliciet dat zij het venerisch probleem niet 'moralistisch', maar wel vanuit een louter sanitair-medisch standpunt benaderden. Toch geeft ook hun vertoog over de venerische ziekten overduidelijk blijk van een bezorgdheid om de moraal. Het Belgisch leger had in de negentiende en het begin van de twintigste eeuw op moreel vlak een bijzonder kwalijke reputatie. In de maatschappij leefde de idee dat de kazerne een oord van verderf en losbandigheid was,

1 Dit artikel kwam tot stand in het kader van een project over het degeneratiedenken in wetenschap en cultuur in België (1850-1950), dat wordt gefinancierd door het Fonds voor Wetenschappelijk Onderzoek Vlaanderen. Dank ben ik verschuldigd aan J. Tollebeek en aan K. Wils voor hun kritische opmerkingen bij een eerdere versie van dit artikel.

2 P. Scholliers schaart zich wat de alcoholbestrijding in België betreft uitdrukkelijk achter deze moraliserings- en disciplineringsthese. Zie: "Een vijand dien men kennen moet'. Jenever in België in de negentiende en vroege twintigste eeuw', in: E. van Schoonenberghe, ed., Jenever in de lage landen (Brugge, 1996) 138-157. A. M. Brandt omschrijft de strijd tegen de geslachtsziekten in de Verenigde Staten in hoofdzaak als een moraliseringsoffensief. Volgens hem werden de venerische ziekten de voorbije twee eeuwen vooral aangewend voor de regulering van het seksueel gedrag. De venerische ziekten werden verbonden met illegitieme seksualiteit en de oplossing voor het geslachtsziektenprobleem werd louter in gedragsveranderingen gezocht. Zie: A. M. Brandt, No magie bullet. Asocial history of venereal disease in the United States since 1800 (New York, Oxford, 1987). Vgl. K. Velle, 'De syfiliskwestie in België in de negentiende en het begin van de twintigste eeuw', Tijdschrift voor sociale wetenschappen, IV (1987) 331363; R. Davidson, 'Venereal disease, sexual morality, and public health in interwar Scotland', Journal of the history of sexuality, XXI (1994) 267-294.

3 Zie bijvoorbeeld A. Mooij, Geslachtsziekten en besmettingsangst. Een historisch-sociologische studie 1850-1990 (Amsterdam, 1993)35, 111-112. 
een plaats waar alcoholische dranken rijkelijk vloeiden en onzedelijke praktijken tot de dagelijkse realiteit behoorden. Juist in de radicale bestrijding van de geslachtsziekten en ook van het drankmisbruik bij soldaten zagen de Belgische legerartsen een efficiënte manier om de morele toestand in het leger te verbeteren, om het leger moreel te verheffen. In dit opstel wil ik dan ook betogen dat de Belgische militaire artsen met hun offensief tegen de venerische ziekten en het drankmisbruik bij soldaten zeker niet alleen een verbetering van de gezondheidstoestand in de kazerne beoogden, maar dat zij daarmee ook ontegensprekelijk morele doeleinden nastreefden.

Bij de strijd tegen de venerische ziekten en het alcoholisme in het leger gingen sanitaire en morele drijfveren hand in hand. Ze raakten bovendien verweven met andere motieven, die niet altijd even helder van het sanitair-morele motivatiecomplex te onderscheiden zijn: het vergroten van de faam en het prestige van het leger, het verhogen van de militaire en nationale efficiëntie, de regeneratie van het ras. Een tweede opzet van dit opstel bestaat erin om ook de rol van deze motieven bij het drank- en venerisch offensief van de Belgische legerartsen te verduidelijken.

Als belangrijkste bron voor dit opstel diende het tijdschrift van de gezondheidsdienst van het Belgisch leger. In januari 1848 kregen de artsen van de Belgische strijdmacht een eigen forum: voor het eerst verschenen de Archives de médecine militaire (in het vervolg kortweg de Archives genoemd). Voor hoofdredacteur Armand Meynne ${ }^{4}$, een sociaalvoelende legerarts en hygiënist die in 1865 met zijn Topographie médicale de Belgique internationale faam zou verwerven, kondigde het tijdschrift een nieuw tijdperk voor de militaire geneeskunde in België aan. Al te lang was de gezondheidsdienst van het leger door artsen gebruikt als een opstapje voor een carrière in de burgerlijke samenleving. In de toekomst zouden artsen hun ambities binnen de gezondheidsdienst van de strijdmacht kunnen realiseren. De Archives moesten de professionele belangen van de legerartsen verdedigen. Maar daarnaast had het blad ook uitdrukkelijk wetenschappelijke oogmerken. Het publiceerde zowel artikelen over medische problemen die eigen waren aan het militaire milieu (zoals oorlogsblessures) als bijdragen van algemeen geneeskundige aard. De Archives ontpopten zich in de tweede helft van de negentiende en het begin van de twintigste eeuw tot één van de meest toonaangevende geneeskundige tijdschriften van België ${ }^{5}$.

4 Over Meynne: K. Veile, 'Armand Joseph Meynne. Legerarts en sociaal denker', in: J. de Maeyer, e. a., ed., Er is leven voor de dood. Tweehonderd jaar gezondheidszorg in Vlaanderen (Kapellen, 1998) 108-110.

5 De opzet van het tijdschrift wordt uiteengezet in: A. Meynne, 'A nos collègues de l'armée', Archives de médecine militaire, I (januari 1848) i-vi. Zie ook K. Veile, 'Bronnen voor de medische geschiedenis. De Belgische medische pers (begin XIXde eeuw-1940)', Annalen van de Belgische vereniging voorde geschiedenis van de hospitalen en de volksgezondheid, XXIII-XXIV (1985-1986) 83; R. François, 'Geschiedenis van het militaire medische tijdschrift', in: E. Evrard, J. Mathieu, ed.,Asklepios onder de wapens. 500 Jaar militaire geneeskunde in België (Brussel, 1997) 459-469. Het tijdschrift verschijnt vandaag nog steeds, zij het als Annales medicinae militaris Belgicae. Onder meer tijdens de twee wereldoorlogen werd de publicatie ervan wel kortstondig (niet voor de volledige duur van de oorlogen) gestaakt. François geeft een overzicht van de vele naamsveranderingen die het tijdschrift heeft ondergaan (460). Het eerste nummer droeg bijvoorbeeld de titel Archives de médecine militaire, vanaf 1849 heette het Archives belges de médecine militaire, vanaf 1863 Archives médicales belge enzovoort. In wat volgt geef ik de titel van het tijdschrift in alle gevallen verkort als Archives weer. 


\section{GESLACHTSZIEKTEN EN ALCOHOLISME IN DE ARCHIVES}

Het venerisch probleem en het alcoholisme, in de tweede helft van de negentiende en de eerste helft van de twintigste eeuw brandende kwesties in de medische wereld, konden ook bij de Belgische legerartsen op bijzondere belangstelling rekenen. Er rustte in $d c$ Archives in geen geval een taboe op de geslachtsziekten. Al ging de aandacht in de eerste jaargangen vooral uit naar cholera en oftalmie ${ }^{6}$, toch werden ook de venerische ziekten van bij het begin onbeschroomd besproken ${ }^{7}$. De Archives volgden het onderzoek over de geslachtsziekten op de voet, vaak met originele bijdragen, soms aan de hand van artikelen die - eventueel in samenvatting - uit buitenlandse (vooral Franse) medische tijdschriften werden overgenomen. Het tijdschrift biedt dan ook een mooi overzicht van de frustraties en successen die de Venerologie in de tweede helft van de negentiende en de eerste helft van de twintigste eeuw beleefde.

In de tweede helft van de negentiende eeuw waren het vooral frustraties, want ondanks het uitgebreid wetenschappelijk onderzoek werd er toen nauwelijks enige vooruitgang in de kennis over de geslachtsziekten geboekt. Ook de therapeutische bestrijding van de ziekten bevond zich duidelijk in een impasse. Voor de behandeling van gonorroe werd vooral naar spoelingen met kaliumpermanganaat of zilvernitraat gegrepen, maar echte genezing van de ziekte werd daarmee zelden bereikt. Aan syfilispatiënten werd meestal een kwikbehandeling voorgeschreven, maar sommige artsen beweerden dat patiënten daar meer schade van ondervonden dan dat ze er baat bij hadden. De syfilisatiepogingen van de Franse arts Auzias-Turenne, die in het begin van de jaren vijftig in de Archives ruime aandacht kregen, liepen met een sisser af $^{8}$. De hele tweede helft van de negentiende eeuw zochten artsen koortsachtig maar tevergeefs naar een specifiek geneesmiddel tegen de verschillende geslachtsziekten. In de Archives werd bij wijlen heftig gediscussieerd over de heilzaamheid van bepaalde therapeutische middeltjes die aan venerische patiënten werden toegediend.

6 Oftalmie (oogontsteking) vormde tot het laatste kwart van de negentiende eeuw een echte plaag in het Belgisch leger. Soms zochten legerartsen de oorzaak van deze aandoening in geslachtsziekten als syfilis of gonorroe. Zie D. D. Edwards, 'Microbiology of the eye and ophthalmia', in: D. M. Albert, D. D. Edwards, ed., The history ofophthalmology (Cambridge, 1996) 147-183.

7 In het prestigieuze artsenblad Le scalpel verschenen in de jaren vijftig ook geregeld artikelen over de diagnose en behandeling van geslachtsziekten. In het hygiënistisch tijdschrift Le mouvement hygiénique $(\mathrm{MH})$ daarentegen werd het onderwerp doodgezwegen. Tot 1899, het jaar van de eerste internationale conferentie over de venerische ziekten, wijdde het nauwelijks meer dan enkele regels aan syfilis of de daarmee verbonden prostitutiekwestie. Hoofdredacteur Belval was zich van die leemte bewust. Hij wijtte ze aan 'la difficulté à traiter ce sujet scabreux entre tous'. Zie: MH, lil (december 1887) 478. Le mouvement hygiénique richtte zich dan ook op een breed geïnteresseerd publiek, terwijl het lezerspubliek van de $A r$ chives en Le scalpel uitsluitend uit artsen bestond.

8 Auzias-Turenne geloofde dat men gezonde mensen immuun kon maken tegen syfilis door ze met het syfilisvirus in te enten. De Franse Academie voor geneeskunde veroordeelde in 1852 de syfilisatie. In de Archives verschenen in de jaren vijftig bijna maandelijks fragmenten uit de 'Cours de syphilisation' van Auzias-Turenne. Ook na de veroordeling van de syfilisatie in Frankrijk zetten de Archives de publicatie hiervan verder. Toch bleef de syfilisatietheorie in de Archives zeker niet vrij van kritiek. Zie bijvoorbeeld Binard, 'Sur la syphilisation'. Archives, X (mei-juni 1857) 399-405 en Verheyen, 'Considérations sur trois faits de la médecine contemporaine, présentées à l'Académie royale de médecine', Archives, XI (januari 1858)28-53 
In het begin van de twintigste eeuw kwam het onderzoek over de geslachtsziekten echter in een stroomversnelling terecht. In 1905 slaagden Fritz Schaudinn en Erich Hoffmann erin de bacterie die syfilis veroorzaakt, de treponema pallidum, af te zonderen 9 . In 1906 werd de serodiagnostiek van Bordet-Wassermann op punt gesteld en in 1910 maakte de ontdekking door Paul Ehrlich van salvarsan als medicijn tegen syfilis een eind aan de langdurige therapeutische impasse. Al deze wetenschappelijke successen werden in de Archives op voorzichtig enthousiasme onthaald. Legerartsen deden in de militaire hospitalen onderzoek naar de zenuwaandoeningen die soms na het toedienen van salvarsan optraden, en zochten naar de beste verhouding tussen salvarsan en kwik of salvarsan en bismuth voor de zogenaamde gemengde behandeling van syfilis, die dit soort zenuwaandoeningen moest voorkomen. Na de Tweede Wereldoorlog verschenen in de Archives de eerste berichten over de penicilline. Die leek een volledige genezing van de geslachtsziekten te garanderen en zou dan ook weldra op algemene schaal worden ingevoerd ${ }^{10}$.

Naar het alcoholprobleem ging in de Archives proportioneel gezien minder aandacht uit. Toch bracht het tijdschrift geregeld verslag uit over het onderzoek dat in binnenen buitenland werd verricht naar de gevolgen van alcoholische dranken op het menselijk lichaam. In de tweede helft van de negentiende eeuw ontdekten artsen het alcoholisme als 'ziekte'. Drankmisbruik evolueerde van een zonde naar een pathologisch verschijnsel, een medisch studieobject ${ }^{11}$. Artsen gingen minutieus na welke schade alcohol in het menselijk organisme kon aanrichten. Ook een aantal legerartsen hield zich met dergelijk onderzoek bezig. Assistent-arts Van Vyve bijvoorbeeld beschreef in 1878 in de Archives de ravages die alcoholexcessen in het lichaam van een drieënvijftigjarige brigadier hadden aangericht en uiteindelijk zelfs tot de dood van de onverbeterlijke jeneverdrinker hadden geleid $^{12}$.

Alcoholmisbruik kwam in de Archives echter vooral ter sprake als oorzaak en versnellende factor van allerhande ziekten, bijvoorbeeld van de geslachtsziekten. Tussen alcoholmisbruik en venerische ziekten werd in de tweede helft van de negentiende en het begin van de twintigste eeuw een nauw verband verondersteld ${ }^{13}$. Aangenomen

9 In 1879 had A. Neisser al de bacterie die gonorroe veroorzaakt, de gonokok, ontdekt.

10 Voor het negentiende- en twintigste-eeuwse onderzoek over de geslachtsziekten: E. Bäumler, Amors vergifteter Pfeil. Kulturgeschichte einer verschwiegenen Krankheit (Hamburg, 1976); J. T. Crissey, L. C. Parish, The dermatology and syphilology of the nineteenth century (New York, 1981 ); C. Quétel, Le mal de Naples. Histoire de la syphilis (Parijs, 1986). Voor België: Craps, Jacqué, 'La dermatologie et la syphiligraphie en Belgique pendant un siècle', in: Cent ans de médecine en Belgique (1830-1930) (Brussel, 1931) 193-268; P. Rebmann, 'Syfilis, 1830-1860. Een historisch en wetenschapskritisch onderzoek naar de medische constructie van een epidemie' (Onuitgegeven licentiaatsverhandeling KU Leuven; Leuven, 1989); Idem, 'Syfilis 1834-1850. De geboorte van een epidemie', Belgisch tijdschrift voor nieuwste geschiedenis (BTNG), XXII (1991) 569-623.

11 Zie hiervoor D. Nourrisson, Alcoolisme et antialcoolisme en France sous la troisième république. L'exemple de la seine inférieure (Parijs, 1988); Idem, Le buveur au 19e siècle (Parijs, 1990). Vgl. G. Johnstone, 'From vice to disease? The concepts of dipsomania and inebriety, 1860-1908', Social and legal studies. An international journal, V (1996) 37-56.

12 Van Vyve, 'Ulcère de l'estomac chez un alcoolique. Sclérose du pancréas', Archives, XXX (oktober 1877)247-252.

13 Daarnaast was bij artsen ook het verband tussen drankmisbruik en tuberculose populair. Legerartsen 
werd dat geslachtsziekten bijna altijd in benevelde toestand werden opgelopen. Legerartsen waren ervan overtuigd dat ook de venerische ziekten bij soldaten meestal aan excessief drankgebruik te wijten waren. Daarom raadde legerarts Charles Petithan zijn rekruten steevast aan om nooit in beschonken toestand een vrouw te ontmoeten ${ }^{14}$. Mensen die al aan een venerische ziekte leden, werd ten zeerste afgeraden nog alcoholische dranken te consumeren. Eén enkel alcoholexces kon - aldus sommige legerartsen - het ziekteproces drastisch versnellen of ernstige complicaties veroorzaken $^{15}$.

Het alcoholvraagstuk en het geslachtsziektenprobleem konden beide op grote belangstelling van de legerartsen rekenen en ze werden vaak zo sterk met elkaar verweven dat er eigenlijk nog slechts sprake was van één en hetzelfde probleem. Het feit dat in de kringen van militaire geneeskundigen zoveel aandacht naar de venerische ziekten en het drankmisbruik uitging, hield niet alleen verband met de bezorgdheid die in het algemeen over beide 'ziekten' in de medische wereld leefde, maar vindt ook een verklaring in het beeld dat de maatschappij over het soldatenberoep had.

\section{EEN RISICOBEROEP}

In 1985 publiceerde geneesheer majoor Bellens in de Acta médicinalia militaria Belgica, de opvolger van de Archives, een bijdrage over het alcoholprobleem bij de strijdkrachten, maar niet — zo stelde hij uitdrukkelijk — omdat drankmisbruik in het leger meer zou voorkomen dan in de burgerlijke samenleving ${ }^{16}$. In de negentiende en het begin van de twintigste eeuw werd daarentegen wél algemeen aangenomen dat het gevaar voor drankmisbruik bij militairen groter was dan bij gewone stervelingen. Ook hun kans op geslachtsziekten werd hoger geraamd dan die van de modale mens ${ }^{17}$. Soldaten werden in de negentiende en het begin van de twintigste eeuw vaak als een

schreven het hoge aantal tuberculoselijders in het leger ten dele toe aan de alcoholexcessen van soldaten. Zie bijvoorbeeld G. Martin, 'La lutte contre la tuberculose. Les sanatoria populaires de l'empire d'Allemagne', Archives, L1V (april 1901) 331; Lejeune, 'La lutte contre la tuberculose dans l'armée', Archives, LVII (1904) 202-204. Vgl. D. Nourrisson, 'Tuberculose et alcoolisme ou du bon usage d'un aphorisme', in: J.-P. Bardet, e. a.. Peurs et terreurs face à la contagion. Choléra, tuberculose, syphilis XlXe-XXe siècle (Parijs, 1988) 199-217; D. S. Barnes, The making of a social disease. Tuberculosis in nineteenth-century France (Berkeley, Los Angeles, Londen, 1995) 138-173. Verder werden dronkaards ook erg vatbaar geacht voor cholera. Zie onder andere E. Chevalier, Recueil des règlements, instructions, lois, arrêtés et circulaires concernant le service de santé de l'armée (Charleroi, Brussel, 1891) 100.

14 Ch. Petithan, 'Note sur le traitement de l'uréthrite', Archives, XXXI (maart 1863) 226-227. Vgl. F. van den Branden, 'Importance des complications de la blennorrhagie', Archives, LXXII1 (februari 1920) 100 .

15 Zie bijvoorbeeld E. Henrotay, 'Considérations sur les écoulements de l'urètre et leur traitement'. Archives, III (september 1850) 184; Semet, 'Hôpital militaire de Liège. Note sur un cas de syphilis maligne observé dans le service de M. le médecin de régiment de Ire classe Hymblet', Archives, L (april I897) 245. 16 A. Bellens, 'Het alcoholprobleem en de strijdkrachten', Acta médicinalia militaria Belgica, CXXXVII (1985)124-126.

17 Tussen het soldatenberoep en syfilis werd al vele eeuwen een verband gelegd. Zie O. Temkin, 'On the history of 'morality and syphilis", in: O. Temkin, The double face of Janus and other essays in the history of medicine (Baltimore, Londen, 1977) 477. 
risicogroep voor alcoholisme en venerische ziekten beschouwd. Het leger werd door velen aangezien als een leerschool voor alcohol- en venerische excessen ${ }^{18}$. Het was een gemeenplaats dat jongemannen tijdens hun kazernejaren in een leven van ontucht en losbandigheid verzeild raakten. De populaire literatuur staat bol van de anekdotes over jonge rekruten die in het leger hun kuisheid voor een zedeloze levensstijl inruilden en daaraan één of andere geslachtsziekte overhielden ${ }^{19}$. Vooral in katholieke kringen werd vaak hard geklaagd over de belabberde moraal in het leger ${ }^{20}$.

Ook de medische wereld verdacht het soldatenvolk van een decadente en liederlijke levenswandel, die zich wreekte met de meest gruwelijke venerische ziekten.

On sait qu'aussitôt que les militaires ont recouvré toute leur indépendance, ordinairement le premier usage qu'ils en font c'est de s'enivrer, et le second c'est d'aller se vautrer dans les maisons de débauche, d'où ils sortent souvent avec la maladie qu'ils emportent alors avec eux pour la répandre dans la campagne,

schreef een commissie van artsen in de jaren $1830^{21}$. De commissie moest een oordeel vellen over de verhandelingen die waren ingestuurd als antwoord op de prijsvraag van het Brussels medisch congres van 1835. De organisatoren van dat congres wilden achterhalen met welke maatregelen het syfilisprobleem het best kon worden bestreden. In bijna alle ingestuurde verhandelingen werd bijzondere aandacht gevraagd voor het 'risicovolle' soldatenberoep.

Zelfs de legerartsen timmerden vlijtig mee aan de topos van de losbandige soldaat. Ook zij wezen op de bijzondere vatbaarheid van (vooral jonge) rekruten voor drankmisbruik en geslachtsziekten en ze haalden hiervoor een resem verklaringen aan. In de eerste plaats maakte de leeftijd van de soldaten dat zij zich sterk tot het vrouwelijk geslacht aangetrokken voelden. Bovendien viel in de kazerne elke moraliserende invloed van familieleden weg. Oudere soldaten gaven vaak het slechte voorbeeld aan de jongere rekruten. Daarnaast bracht ook heimwee naar het ouderlijke nest jonge

18 Dat was niet alleen in België het geval. Ook in vele andere landen leefde bij de publieke opinie de idee dat het leger een oord van verderf was. Zie hiervoor onder andere H. L. Wesseling, Soldaat en krijger. Franse opvattingen over leger en oorlog aan de vooravond van de Eerste Wereldoorlog (Amsterdam, 1988) 33-34; E. W. R. van Roon, 'De dienstplicht op de markt gebracht. Het fenomeen dienstvervanging in de negentiende eeuw', Bijdragen en mededelingen betreffende de geschiedenis der Nederlanden (BMGN), CIX (1994) 617; D. M. Peers, 'Soldiers, surgeons and the campaigns to combat sexually transmitted diseases in colonial India, 1805-1860', Medical history, XLII (1998) 139-140, 147.

19 Bijvoorbeeld A. van lersel, De kanker der samenleving. Siphilis. Realistische zedenschets (Antwerpen, s. a.j.

20 Zie onder andere de tussenkomst van de aalmoezenier van het militair kamp van Beverloo op het katholieke Congrès des oeuvres sociales. In: Congrès des oeuvres sociales à Liège 26-29 septembre 1886 (Luik, 1886)483-491.

21 Bigot, Daumerie, Canstatt, Mémoires couronnés par le congrès médical de Belgique, sur la question suivante, proposée pour sujet de prix. Exposer et déterminer les moyens médicaux et les mesures administratives et réglementaires propres à arrêter ou à modérer la propagation de la syphilis, suivis du rapport général sur le concours (SA., s. a.) 90. De idee dat soldaten in belangrijke mate bijdroegen tot de verspreiding van de geslachtsziekten op het platteland, werd door vele negentiende en vroeg-twintigsteeeuwse artsen aangehangen. Zie bijvoorbeeld ook: Lamelle, 'Conférence internationale pour la prophylaxie de la syphilis et des maladies vénériennes', MH, XV (1899) 293-294. 
militairen volgens de legerartsen soms van het rechte pad. In vredestijd dreef de verveling de soldaten naar de drankgelegenheden in de buurt van de kazerne, in oorlogstijd meenden militairen kracht en moed uit de drank te putten. Soldaten grepen ook gemakkelijk naar de fles om een militaire overwinning te vieren. Maar vooral hun volstrekte onwetendheid op seksueel gebied maakte de jonge rekruten, vooral die van het platteland, in de ogen van de legerartsen tot een bijzonder gemakkelijke prooi voor immoreel en bandeloos gedrag. De al genoemde militaire arts Petithan schreef in 1863 :

On peut affirmer, pour l'honneur ou plutôt la vertu de nos conscrits campagnards, que beaucoup d'entre eux arrivent au service vierges encore, sinon tout à fait innocents. Ils commencent à servir Cupidon sous les drapeaux, et comme on ne leur apprend guère l'exercice du milieu malin, il arrive qu'ils le servent mal et qu'ils blessent souvent leur propre arme ${ }^{22}$.

Ook de legerartsen droegen zonder twijfel bij tot de verspreiding van het beeld dat het leger een kweekschool van zedeloze en verdorven mannen was, waar drankmisbruik en geslachtsziekten een vruchtbare voedingsbodem vonden. De vraag of het alcohol- en geslachtsziektenprobleem in het leger ook daadwerkelijk veel dramatischer proporties aannam dan daarbuiten, wordt verder in dit opstel beantwoord.

\section{DE PLAATSVERVANGERS}

Er was één categorie soldaten die door de legerartsen in het bijzonder verantwoordelijk werd gesteld voor de slechte morele reputatie van het leger: die van de plaatsvervangers. De Belgische troepen werden in de negentiende eeuw door loting samengesteld, maar vaak lieten gegoede (en steeds meer ook minder gegoede) ingelote mannen zich tegen betaling vervangen door jongelui uit de laagste klassen van de samenleving. Heel wat legerartsen verweten deze plaatsvervangers dat ze door hun baldadig en ongedisciplineerd gedrag de moraal in het leger ondermijnden. Volgens hen spendeerden de plaatsvervangers al hun vrije tijd en geld in louche drankgelegenheden in de buurt van de kazernes en spoorden zij de andere soldaten aan tot navolging van hun losbandige levensstijl.

Regimentsarts Auguste Jansen, bekend om zijn niet aflatende strijd tegen het alcoholisme, gaf in 1876 zijn misprijzen voor de plaatsvervangers bijzonder weinig omfloerst te kennen:

Les remplaçants, dont la moralité laisse tant à désirer, ont le plus souvent déjà avant leur entrée au service des habitudes d'ivrognerie. Les marchands d'hommes les recrutent dans la lie de la société. Pour les découvrir, ils parcourent les quartiers pauvres et populeux, faisant dans les cabarets de bas étage un appel aux fainéants, aux déclassés et concluent le 
marché entre deux verres d'eau-de-vie. A partir de ce moment jusqu'au jour de l'incorporation, le vendu passe son temps dans l'orgie et il y perd souvent ce qui lui reste d'argent, de santé et d'honnêteté. Dès leur arrivée au dépôt, ils deviennent les hôtes assidus des cabarets voisins du quartier et de la cantine de l'agent du casernement. Ils y dépensent en peu de jours leur prime d'engagement. Ces hommes vicieux sont toujours de mauvais soldats et l'exemple qu'ils donnent aux jeunes troupiers est des plus pernicieux ${ }^{23}$.

Legerartsen wezen de plaatsvervangers niet alleen aan als de schuldigen voor het alcoholprobleem, maar ook bijvoorbeeld voor het hoge aantal geslachtsziekten in het leger. Hun beperkte scholing en hun ontuchtige levenswandel maakten hen op dit vlak uiterst verdacht ${ }^{24}$.

Voor de legerartsen was de demoraliserende invloed van de plaatsvervangers een voldoende argument om voor de afschaffing van de plaatsvervanging en de invoering van de persoonlijke dienstplicht te pleiten. Heel wat legerartsen beweerden dat de afschaffing van de plaatsvervanging het alcoholmisbruik en de venerische ziekten in het leger drastisch zou terugdringen en tot een moreel herstel van de strijdkrachten zou leiden ${ }^{25}$. Petithan bijvoorbeeld hield eind september 1886 op het katholieke Congrès des oeuvres sociales in Luik, vanuit zijn bekende bekommernis om de moraal in het leger, een krachtig pleidooi voor de afschaffing van de plaatsvervanging en de invoering van de persoonlijke dienstplicht. Om te verhinderen datjonge militairen in het leger nog langer in contact zouden komen met 'des hommes tarés' wilde hij niet alleen de plaatsvervangers uit het leger zien verdwijnen, maar ook alle 'mauvais volontaires', de jongemannen die slechts naar het leger werden gestuurd omdat er verder niets met hen viel aan te vangen. Volgens Petithan was het uiterst gevaarlijk om het leger louter uit de laagste klassen van de samenleving te rekruteren ${ }^{26}$.

23 A. Jansen, 'De l'usage et de l'abus des boissons alcooliques dans l'armée', Bulletin de la société de médecine d'Anvers, XXXVII (1876) 502-503.

24 Zie bijvoorbeeld Ch. Petithan. 'Prophylaxie des maladies vénériennes', Archives, XXVII (november 1885) 357. De meeste officieren en vele dienstplichtigen deelden deze misprijzende houding tegenover de plaatsvervangers. Ook zij uitten frequent hun ongenoegen over de geringe intellectuele ontwikkeling van deze soldaten, over hun immoreel en ongedisciplineerd gedrag, over het hoog aantal criminele daden en deserties in hun rangen enzovoort. Zie hiervoor: L. de Vos, Het effectief van de Belgische krijgsmacht en de militiewetgeving, 1830-1914 (Brussel, 1985)64, 183-184. Vgl. B. Schnappet, Le remplacement militaire en France. Quelques aspects politiques, économiques et sociaux du recrutement au XIXe siècle (Parijs, 1968) 150-153, 280; Van Roon, 'De dienstplicht op de markt gebracht', 617; R. Spork, 'De discussie over het remplaçantenstelsel in Nederland 1873-1898', De negentiende eeuw, IX (1985) 56-57.

25 Heel wat tegenstanders van de persoonlijke dienstplicht (in hoofdzaak katholieken) verwezen evenzeer naar de immorele toestand in het leger om hun standpunt te bepleiten. Zij hoopten met het behoud van de plaatsvervanging zoveel mogelijk jongemannen uit de betere klassen te behoeden voorde nefaste moraal die volgens hen in de kazernes heerste. Zie bijvoorbeeld C. Verfaillie, ' Katholiek verweer tegen de persoonlijke dienstplicht (1886-1887)' (Onuitgegeven licentiaatsverhandeling KU Leuven; Leuven, 1983) 39-40; De Vos, Het effectief van de Belgische krijgsmacht, 184-186.

26 Congres des oeuvres sociales, 505-512. Vgl. 'De la prostitution. (Extraits de rapports)'. Archives, XXXIV (november 1888) 349; V. de Vaucleroy, De l'alcoolisme dans l'armée et des moyens de le combattre (Brussel, 1900) 3. Slechts één keer vond ik in de Archives kritiek op de stigmatisering van de plaatsvervangers en van bepaalde vrijwilligers in het leger. In 1878 reageerde assistent-arts Van Vy ve kribbig op de verwijten die Petithan tegen de 'mauvais volontaires' had gespuid: 'S'il est vrai qu'une certaine catégorie de soldats abandonnent leur prime dans les cabarets, nous devons reconnaître aussi que les volontaires avec primes 
De strijd die de artsen van het Belgisch leger — met de steun van de meeste officieren trouwens - op het einde van de negentiende eeuw tegen de plaatsvervanging voerden, was in belangrijke mate een strijd om de morele verheffing van het leger. Legerartsen schoven de slechte morele reputatie van de strijdmacht volledig in de schoenen van de plaatsvervangers. Hun abominabele moraal, onder meer af te lezen uit het hoog aantal alcoholici en venerische patiënten dat zich in hun rangen bevond, vormde volgens de militaire artsen een smet op het blazoen van het leger. Alleen de invoering van de persoonlijke dienstplicht, die de ingelote jongemannen uit de hogere klassen van de samenleving zou verplichten om zelf hun legerdienst te vervullen, kon aldus de legerartsen tot een moreel herstel van de strijdmacht leiden. De welopgevoede en degelijk geschoolde mannen uit de betere milieus van het land zouden volgens hen zonder twijfel het moreel gedrag van de soldaten van lagere komaf in gunstige zin beïnvloeden. Het vertoog van de militaire artsen over de plaatsvervangers illustreert dat de strijd tegen de geslachtsziekten en het alcoholisme in het leger zeker niet alleen door sanitaire, maar duidelijk ook door morele aspiraties was ingegeven.

Daarnaast toont dat vertoog aan dat ook in het leger klasse-elementen een rol speelden bij de definiëring van het alcohol- en geslachtsziektenprobleem. Zowel het alcoholisme als de venerische ziekten werden tot een moreel probleem van de laagste rangen van het leger herleid. Al wees af en toe wel eens een arts op het feit dat ook officieren niet 'à l'abri des blessures de Vénus' zijn ${ }^{27}$, toch lag de klemtoon op de groep van arme en ongeschoolde soldaten die uit geldnood gedwongen werd om als plaatsvervanger in het leger een bron van inkomsten te vinden. De legerartsen verdedigden de afschaffing van de plaatsvervanging soms met 'Ie grand principe de l'égalité de tout citoyen devant la loi' en ze beoogden met de invoering van de persoonlijke dienstplicht een soort 'verbroedering' van de verschillende sociale klassen in het leger, maar tegelijkertijd gingen zij duidelijk uit van de morele superioriteit van de hogere standen. Pas in 1909 haalden de legerofficieren in het debat over de rekruteringswijze van het leger hun slag thuis. Een nieuwe militiewet voerde toen de persoonlijke dienstplicht in. Het tijdperk van de plaatsvervanging werd afgesloten ${ }^{28}$.

sont, dans quelques corps, victimes d'injustes préjugés. Sans doute, la plupart de ces volontaires sont loin de constituer l'élite de la société, mais c'est un motif de plus pour que l'influence moralisatrice, qu'on attribue à l'armée, s'exerce sur ces intelligences. Méprisés, repoussés a priori comme de mauvais sujets, ces hommes cherchent dans l'ivresse de l'alcool l'oubli de leurs peines et finissent par y prendre ce qui leur restait de dignité', in: 'Des moyens de combattre l'ivrognerie dans l'armée', Archives, XIV (december 1878)455.

27 Petithan, 'Prophylaxie des maladies vénériennes', 352.

28 België schafte de plaatsvervanging met een ruime vertraging op de andere Europese landen af. In Frankrijk was dat bijvoorbeeld al in 1872 gebeurd. Nederland voerde in 1898 de persoonlijke dienstplicht in. Voor de eindeloze debatten die tussen 1830 en 1914 in België over de rekruteringswijze voor het leger werden gevoerd, zie De Vos, Het effectief van de Belgische krijgsmacht. Vgl. Schnapper, Le replacement militaire; V. G. Kiernan, 'Conscription and society in Europe before the war of 1914-1918', in: H. J. Kaye, ed., History, classes and nation-states. Selected writings of V. G. Kiernan (Oxford, 1988) 166-185; W. Klinkert, Het vaderland verdedigd. Plannen en opvattingen over de verdediging van Nederland 18741914 (Den Haag, 1992); H. te Velde, Gemeenschapszin en plichtsbesef. Liberalisme en nationalisme in Nederland 1870-1918 (Den Haag, 1992) 41-49, 53-55, 97-99. 


\section{DE PROSTITUEE}

In het garnizoen werden de plaatsvervangers verantwoordelijk gesteld voor het alcoholen geslachtsziektenprobleem bij de soldaten, maar de hoofdschuldige zochten de legerartsen buiten de muren van de kazerne: de prostituee ${ }^{29}$. De prostituee — zo luidde het cliché - lokte de soldaten met haar provocerende blik en haar uitdagende kledij mee naar één van de vele bordelen of verdachte drankgelegenheden in de buurt van de kazerne. Daar voerde ze de soldaten in een snel tempo dronken. Geïnfecteerd met een venerische ziekte verlieten die enige tijd later het gore etablissement. Van dat ogenblik af vormden ze volgens de militaire geneesheren een ernstige bedreiging voor het hele garnizoen ${ }^{30}$. In de ogen van de legerartsen betekende de prostituee zowel een sanitair als een moreel gevaar voor de soldaten. Aan de ene kant leefde bij die artsen de idee dat de prostituee de belangrijkste haard van besmetting voor geslachtsziekten bij soldaten was. Aan de andere kant bevatten de geschriften van negentiendeen vroeg-twintigste-eeuwse legerartsen ook eindeloze reeksen klachten over het wanvoeglijk en aanstootgevend gedrag van de publieke vrouwen, waaruit blijkt dat voor hen de prostituees, net zoals de plaatsvervangers, ook als zondebok fungeerden voor de verdorven morele toestand in het leger. In 1841 becommentarieerde de arts Marinus als volgt een Koninklijk Besluit van 1 mei 1838 dat bepaalde dat militairen de nacht niet mochten doorbrengen in ontuchthuizen: 'On ne peut qu'applaudir à cette mesure toute dans l'intérêt de la morale et de la santé du soldat ${ }^{31}$.

\section{Pleitbezorgers voor prostitutiereglementering}

Legerartsen hadden meestal weinig oog voor de sociale omstandigheden die vrouwen in de prostitutie dreef. Prostituees werden omschreven als 'êtres dégradés' of 'viles créatures', als gedegenereerde vrouwen die uit wellust of winstbejag hun eigen lichaam verkochten. In 1913 bijvoorbeeld schreven de militaire artsen Rulot en Sacré naar aanleiding van het geslachtsziektenprobleem in een handboek voor jonge soldaten: 'Le danger, la source du mal, c'est la fille publique, la femme qui se donne à tous par bestialité ou par intérêt ${ }^{32}$. Met dit soort brute formuleringen hoopten ze de soldaten blijkbaar een instinctieve afkeer voor de prostitutie bij te brengen. Rulot en Sacré wilden de rekruten immers aansporen tot seksuele onthouding. De idee dat seksuele onthouding voor mannen mogelijk en niet schadelijk was, had op het einde van de

29 Al vele eeuwen werd er een verband gelegd tussen de soldaat en de prostituee. Zie Quétel, Le mal de Naples, 283-284.

30 Hierbij dachten de toenmalige legerartsen niet in de eerste plaats aan verspreiding van de venerische ziekten onder de soldaten via homoseksuele contacten, maar wel via allerlei niet-venerische vormen van besmetting (bijvoorbeeld door besmette drinkbekers of pijpen), die in de negentiende en het begin van de twintigste eeuw ook door artsen buiten het leger als een reëel gevaar werden beschouwd.

31 J.-R. Marinus, Essai sur l'hygiène du soldat ou exposé des moyens propres à l'entretien de la santé des gens de guerre (Brussel, 1841) 17-19. Een soortgelijke bepaling werd opgenomen in de wet van 14 augustus 1887: 'Loi relative au logement des troupes en marches et en cantonnement et aux prestations militaires', Journal militaire officiel (JMO) (1887) 258-264.

32 Rulot, Sacré, La vie du soldat Belge. Considérations et conseils relatifs à l'éducation et à l'hygiène militaires (Brussel, [1913]) 129. 
negentiende eeuw al ruime ingang gevonden bij civiele artsen. Met enige vertraging drong deze idee in het begin van de twintigste eeuw ook door tot de kringen van de militaire geneeskundigen.

Die hadden zich in de tweede helft van de negentiende eeuw echter bijzonder verknocht getoond aan de idee dat het celibaat voor mannen onmogelijk (en zelfs ongezond) was. Legerartsen namen toen aan dat mannen die geen 'natuurlijke' seksuele betrekkingen konden hebben, hun toevlucht zochten in pervers seksueel gedrag. Om te vermijden dat mannen hun natuurlijke seksuele driften in masturbatie of in de aanranding van eerbare vrouwen zouden botvieren, was het volgens hen beter om prostitutie toe te laten. Legerartsen zagen in de tweede helft van de negentiende eeuw (en velen ook nog in het begin van de twintigste eeuw) prostitutie als een noodzakelijk en onuitroeibaar kwaad. Ze wierpen zich op als heftige pleitbezorgers voor de gereglementeerde prostitutie ${ }^{33}$. Het systeem van het reglementarisme hield in dat de prostitutie niet werd bestreden, maar wel werd onderworpen aan een systematische controle van de zedenpolitie. Prostituees moesten zich laten registreren en geregeld een medisch onderzoek op geslachtsziekten ondergaan. Werd tijdens zo'n onderzoek een geslachtsziekte vastgesteld, dan werd de betreffende prostituee geïsoleerd. Het negentiende-eeuwse reglementarisme was een uitvinding van de Parijse hygiënist Parent-Duchâtelet. Hij werkte in 1836 een prostitutiereglement voor de Franse hoofdstad uit. Dit reglement werd in de loop van de negentiende eeuw door verschillende Europese steden overgenomen ${ }^{34}$.

Net als in vele andere landen oefenden ook in België de legerartsen sterke druk uit om een strikte vorm van prostitutiereglementering ingevoerd te krijgen. In de jaren vóór 1850 liet vooral chirurg Louis-Joseph Seutin zich op dit vlak niet onbetuigd. Seutin was in 1831 aangesteld tot opperarts van het Belgisch leger en maakte - ondanks de afschaffing van dit ambt in 1840 - tot 1854 deel uit van het kader van de

33 Zie bijvoorbeeld het rapport dat Petithan in 1890 voorstelde aan de commissie die in het parlement over de prostitutiekwestie was aangesteld: Documents parlementaires. Recueil des pièces imprimées par ordre de la chambre des représentants, $n r$. 136, séance du 5 avril 1892. Commission chargée de préparer un projet de loi sur la police des moeurs, procès-verbaux des séances de la section d'hygiène (S. 1., s. a.) 140 .

34 Standaardwerken over de geschiedenis van de prostitutie en het reglementarisme zijn: A. Corbin, Les filles de noce. Misère sexuelle et prostitution (19e siècle) (Parijs, 1978); J. R. Walkowitz, Prostitution and Victorian society. Women, class, and the state (Cambridge, 1980). Voor de prostitutiekwestie in België, zie onder andere: S. de Schaepdryver, 'De zonde in banen geleid. Gereglementeerde prostitutie in Brussel, 1844-1877. Onderzoek naar houd(st)ers van getolereerde bordelen' (Onuitgegeven licentiaatsverhandeling VUB; Brussel, 1983); Idem, 'Reglementering van prostitutie, 1844-1877: opkomst en ondergang van een experiment', BTNG, XVI (1985) 473-506; C. Huberty, L. Keunings, 'La prostitution à Bruxelles au XIXe siècle', Les cahiers de la fonderie, Il (1987) 3-22; M.-S. Dupont-Bouchat, 'Verdraagzaamheid en repressie. Fascinatie en weerzin. Elkaar dwarsende blikken op de prostitutie in België (15de-20ste eeuw)', in: Van badhuis tot eroscentrum. Prostitutie en vrouwenhandel van de Middeleeuwen lot heden (Brussel, 1995) 51-87; K. Pittomvils, 'Tussen repressie en permessiviteit. Socialisme, socialisten, prostitutie en geslachtsziekten (einde 19de eeuw-1997)', in: D. de Weerdt, ed., Begeerte heeft ons aangeraakt. Socialisme, sekse en seksualiteit (Gent, 1999) 208-235. Over de prostitutiekwestie in Nederland: P. de Vries, Kuisheid voor mannen, vrijheid voor vrouwen. De reglementering en bestrijding van prostitutie in Nederland, 1850-1911 (Hilversum, 1997); M. Bossenbroek, J.H. Kompagnie, Het mysterie van de verdwenen bordelen. Prostitutie in Nederland in de negentiende eeuw (Amsterdam, 1998). 
strijdmacht. Hij zorgde er onder meer voor dat de Société des sciences médicales et naturelles de Bruxelles in 1834 en het al vermelde Brussels medisch congres in 1835 een prijsvraag over het syfilisprobleem uitschreven, waardoor de problematiek van de prostitutiereglementering in de medische wereld tot een geliefd gespreksonderwerp werd. In 1842 bracht Seutin de prostitutiekwestie zelfs tot op de agenda van de Koninklijke Academie voor geneeskunde, de meest prestigieuze medische instantie van het land. Seutin overtuigde de Academie ervan om bij het ministerie van binnenlandse zaken aan te dringen op legislatieve maatregelen tegen de prostitutie ${ }^{35}$.

Maar de minister van binnenlandse zaken ondernam voorlopig helemaal niets tegen de prostitutie en de venerische ziekten. De bevoegdheid om op te treden tegen de prostitutie was door de gemeentewet van 1836 uitdrukkelijk aan de gemeentelijke overheden toegekend. Brussel voerde in 1844 voor het eerst een officieel prostitutiereglement in. Officieren van het Brusselse garnizoen drongen al van in het begin van de negentiende eeuw bij het gemeentebestuur aan op reglementering, omdat het aantal venerische ziekten in het garnizoen volgens hen snel toenam ${ }^{36}$. Het strikte reglement van Brussel, meestal als hyperreglementarisme getypeerd, kende in Europa een grote uitstraling en werd de basis van vele reglementen die in andere Belgische steden vaak ook onder druk van het plaatselijke garnizoen - werden ingesteld.

De medische kringen van het leger speelden een belangrijke rol bij de invoering van het reglementarisme in België en ze bleven ook de hele tweede helft van de negentiende eeuw de meest heftige verdedigers van het systeem. In de Archives verschenen met regelmaat rapporten van legerartsen over de gezondheidstoestand van de soldaten in verschillende militaire hospitalen van het land. In deze rapporten werd de toename van geslachtsziekten in een bepaald hospitaal bijna altijd toegeschreven aan het slecht toepassen van de prostitutiereglementen of aan het ontbreken van elke reglementering in de stad waar het hospitaal zich bevond ${ }^{37}$. Legerartsen drongen steevast aan op striktere maatregelen tegen de prostitutie en een nauwkeuriger uitvoering ervan. Het liefst van al zagen zij in het hele land een uniforme en strenge reglementering ingevoerd, zodat geen enkele gemeente het probleem nog zou kunnen veronachtzamen. Ook meenden ze dat ze zelf nauwer bij de medische onderzoeken van de prostituees moesten worden betrokken, omdat het syfilisprobleem volgens hen toch vooral in het leger acuut was.

In 1886-1887 debatteerde de Koninklijke Academie voor geneeskunde maandenlang over de zin en onzin van het reglementarisme. In Engeland was op het einde van de jaren zestig en bij het begin van de jaren zeventig, uit protest tegen de Contagious diseases acts die in een aantal Engelse havensteden en garnizoenen een vorm van

35 Zie Des mesures propres à restreindre la maladie syphilitique par une commission composée de MM. Gaux. Lebreau, Seutin, Tallois et Vleminckx, Uittreksel uit Bulletin de l'Académie royale de médecine de Belgique (BARMB) (Brussel, 1843). Over Seutin: Evrard, Mathieu, ed., Asklepios onder de wapens, 114117; V. Jacques, 'Seutin (baron Louis-Joseph)', Biographie nationale, XXII (1914-1921) 324-339; Rebmann, Syfilis 1830-1860, 108-165.

36 Huberty, Keunings, "La prostitution à Bruxelles', 5.

37 Zie bijvoorbeeld 'Rapports semestriels des hôpitaux et infirmeries', Archives, I (januari 1848) 58; 'Rapports semestriels des hôpitaux et infirmeries', Archives, I (april 1848) 227-228. 
prostitutiereglementering hadden ingevoerd, onder leiding van Josephine Butler een abolitionistische beweging tot ontwikkeling gekomen. Die beweging internationaliseerde zich snel en bestond uit een amalgaam van mensen die om uiteenlopende redenen tegen het reglementarisme waren gekant: van feministen die het als een vrouwvijandelijk systeem beschouwden tot moralisten die het als een officiële erkenning van de ontucht bestempelden ${ }^{38}$. In België was vooral de arts Alphonse Moeller een vurig verdediger van het abolitionistisch gedachtegoed. Tijdens het debat in de Academie ging hij onbedaarlijk tekeer tegen het reglementarisme ${ }^{39}$. In de ogen van legerarts Titeca, die voor de Archives verslag uitbracht over het debat, waren de abolitionisten utopisten, die niet wilden beseffen dat de prostitutie onuitroeibaar was en daarom maar beter rigoureus kon worden gecontroleerd ${ }^{40}$. De uiteindelijke conclusie van de Academie dat het reglementarisme moest behouden blijven, werd door de legerartsen met grote tevredenheid onthaald.

Een jaar na het debat in de Academie, in 1888, werd onder impuls van de katholieke minister van justitie Jules Le Jeune in het parlement een speciale commissie aangesteld over de prostitutiekwestie. Die commissie, waarvan onder meer Petithan (intussen op rust) deel uitmaakte, diende een wetsvoorstel over de prostitutie uit te werken. Het voorstel dat uiteindelijk op 21 maart 1891 door de commissie werd aangenomen, beviel Le Jeune allerminst. De commissie stelde voor. om het reglementarisme op bepaalde punten bij te schaven maar het zeker niet af te schaffen, terwijl Le Jeune het systeem liefst zo snel mogelijk in zijn geheel zag verdwijnen. Het wetsvoorstel van de commissie werd nooit bediscussieerd in het parlement en bleef - tot spijt van heel wat legerartsen - zonder enig gevolg ${ }^{41}$.

In het kader van de commissie over de prostitutiekwestie werd een specifiek onderzoek gedaan naar het venerisch probleem in het leger. Er werd een vragenlijst opgesteld die naar verschillende Belgische garnizoenen werd verstuurd. In de Archives verschenen fragmenten uit de binnengekomen antwoorden. Ook deze fragmenten suggereren dat de legerartsen nog steeds unaniem achter het reglementarisme stonden. Alle artsen benadrukten het belang van regelmatige en secuur uitgevoerde medische onderzoeken van de prostituees. In bijna alle fragmenten werd gesmeekt om een hardere bestrijding

38 In geen enkel land was het reglementarisme zo nauw verbonden met het leger als in Groot-Brittannië. De Contagious diseases acts waren op verzoek van de militaire overheden ingevoerd en golden alleen voor soldaten en zeelui. De abolitionisten konden verhinderen dat de acts werden uitgebreid naar de hele bevolking. Zie onder andere M. Trustram, Women of the regiment. Marriage and the Victorian army (Cambridge, 1984) 116-137.

39 Zie A. Moeller, Réglementation de la prostitution. Discours prononcé à l'Académie, le 27 novembre 1886, Uittreksel uit BARMB (Brussel, 1886); Idem, Réglementation de la prostitution. Deuxième discours prononcé à l'Académie, Uittreksel uit BARMB (Brussel, 1887).

40 Titeca, 'Hygiène sociale. Réglementation de la prostitution', Archives, XL (juni 1887) 402-411.

41 Zie bijvoorbeeld de teleurstelling van legerarts Melis: 'Conférence internationale pour la prophylaxie de la syphilis et des maladies vénénennes', Archives, Lil (januari 1900) 71. Voor de commissie en haar wetsvoorstel: Documents parlementaires. Recueil des pièces, $n r$. 136, séance du 5 avril 1892. Commission chargée...; E. Béco, 'État de la législation belge concernant la prostitution", in: Dubois-Havénith, Enquêtes sur l'état de la prostitution et la fréquence de la syphilis et des maladies vénériennes dans les différents pays (Brussel, 1899) 866-871; M. Vincineau, La débauche en droit et le droit à la débauche (Brussel, 1985)51-52,273-289. 
van de clandestiene prostituees, de publieke vrouwen die zich aan de reglementering trachtten te onttrekken ${ }^{42}$. Deze prostituees waren al geruime tijd een doorn in het oog van de legerartsen. Ze werden op het vlak van de geslachtsziekten als bijzonder onveilig beschouwd. Legerartsen zagen het als zorgwekkend dat soldaten om financiële redenen juist vaker bij deze clandestiene prostituees hun toevlucht zochten dan bij de duurdere geregistreerde publieke vrouwen.

In 1899 en 1902 stonden reglementaristen en abolitionisten tegenover elkaar op de eerste twee internationale conferenties over venerische ziekten, die in Brussel door de Belgische veneroloog Dubois-Havénith werden georganiseerd. Legerarts Melis bracht voor de Archives verslag uit over de eerste conferentie en schaarde zich daarbij - hoe kon het anders? - uitdrukkelijk aan de kant van de reglementaristen. In de uiteindelijke resolutie van het congres werd trouwens ook voor een reglementaristisch standpunt geopteerd ${ }^{43}$. Bij het begin van de twintigste eeuw begon de twijfel omtrent de efficiëntie van het reglementarisme echter te groeien. De tweede conferentie in Brussel erkende unaniem het falen van het politionele reglementarisme in de strijd tegen de venerische ziekten. Legerarts Stainforth, verslaggever voor de Archives van deze conferentie, kon zich hiermee blijkbaar wel verzoenen. Uit zijn verslag spreekt alvast geen echte ontevredenheid over het resultaat van de conferentie ${ }^{44}$. Blijkbaar gingen ook legerartsen zich in het begin van de twintigste eeuw langzaamaan kritischer opstellen tegenover het van kracht zijnde reglementarisme. Aan de vooravond van de Eerste Wereldoorlog kantten Rulot en Sacré zich in hun handboek voor jonge rekruten zelfs erg expliciet tegen de prostitutiereglementering, die volgens hen de soldaten een gevoel van schijnveiligheid gaf. Naar hun mening was prostitutie - gereglementeerd of niet - altijd gevaarlijk, was het

une sorte de loterie où l'on gagne presque à tout coup. Et que gagne-t-on? Triste gain que celui d'une maladie souvent incurable ou la perspective de la mort dans le désespoir ou le gâtisme ${ }^{45}$.

\section{De Eerste Wereldoorlog: reglementering of beheersing?}

De Eerste Wereldoorlog bracht in de ogen van de legerartsen zedenverwildering en toegenomen promiscuïteit. In zulke tijden achtten velen onder hen het beter om gereglementeerde bordelen in de buurt van het leger toe te laten om het risico op venerische ziekten bij soldaten te beperken. Al hadden heel wat legerartsen in het begin van de twintigste eeuw hun grenzeloos vertrouwen in de efficiëntie van het regle-

42 Zie Logie, 'De la prostitution', Archives, XLI (september 1888) 199-215; Spruyt, e. a., 'De la prostitution', Archives, XLI (oktober 1888) 265-286 ; 'De la prostitution. (Extraits de rapports)', 348-358.

43 Mélis, 'Conférence internationale pour la prophylaxie de la syphilis et des maladies vénériennes', Archives, LI (december 1899) 404-421, Lil (januari 1900) 56-72.

44 Stainforth, 'Ile Conférence internationale pour la prophylaxie de la syphilis et des maladies vénériennes, sous le patronage du gouvernement belge. (Bruxelles, Ire au 6 sept. 1902)', Archives, LIV (december 1902) 403-421,LV (januari 1903) 41-57, LV (februari 1903) 109-121, LV (maart 1903) 192-206, LV (april 1903) 264-274 en LV (mei 1903) 340-347.

45 Rulot, Sacré, La vie du soldat Belge, 130. 
mentarisme verloren, in oorlogstijd bleven zij erg gewonnen voor het systeem ${ }^{46}$. Er kwamen in België echter geen getolereerde bordelen in de zone van het front. Onder meer de aalmoezeniers van het leger hebben zich daar heftig tegen verzet. Zij riepen de militairen op tot beheersing ${ }^{47}$.

Dat deed ook (de latere flamingantische leider) Frans Daels, die tijdens de oorlog vrijwillig militair arts was aan het front. Hij schreef een aantal pamfletten waarin hij zijn afkeur van elke vorm van prostitutie duidelijk liet blijken. Prostitutie leidde volgens hem tot lichaamsontering en zielsverbastering. In erg pathetische woorden richtte hij zich tot de jongemannen aan het front:

Aan $\mathrm{u}$, jongens van den Yser, die hier in 't gelid staat, overkome dit niet! Gij zijt de ridders van ons land. Uw eerste plicht, na 's lands verdediging, is ridderlijkheid tegenover onze vrouwen. Onteert u niet, duwt geen zwakke vrouw in het verderf of houdt ze niet in ontucht. Ontwikkelt de krachten van uw geslachtsdrift tot kloeke mannelijkheid, tot mannenfierheid en ridderlijkheid. Gij zult u het vurigste, volste liefdegenot voor het leven verzekeren. Jongens, de harten hoog! Mannenadel uit fierheid van het jong geslacht ${ }^{48}$.

Ook in de gretig gelezen frontblaadjes verschenen geregeld soortgelijke aanmaningen ${ }^{49}$.

Maar al deze oproepen tot seksuele beheersing ten spijt leidde de Eerste Wereldoorlog volgens de meeste legerartsen tot een enorme toename van de prostitutie. Heel wat vrouwen die voorheen een 'eerbaar' bestaan hadden geleid, werden door de oorlogsomstandigheden tot prostitutie gedwongen om de kost te verdienen. Bij sommige legerartsen leek er hierdoor iets meer begrip voor de prostituee te groeien. Het besef drong langzaam door dat vrouwen niet noodzakelijk uit geilheid of genotzucht maar vaak uit armoede en ellende in de prostitutie terechtkwamen. Dit lichtjes toegenomen

46 Zie bijvoorbeeld B. Dujardin, 'La lutte antivénérienne à l'Armée', in: Congrès international de médecine et de pharmacie militaires au palais mondial du 15 au 20 juillet 1921 (Brussel, 1921) 11-12; L. Wilmaers, 'Lutte antivénérienne à l'Armée', in: ibidem, 95. De Duitsers voerden in de door hen bezette delen van België een strikte vorm van prostitutiereglementering in. Zie Craps, 'Règlements, législation et contributions médico-sociales belges dans le domaine de la lutte antivénérienne depuis la Tin du XVIIIe siècle jusqu'à nos jours', Archives belges de médecine sociale, hygiène, médecine du travail et médecine légale, VII (1959) 485; C. van Hooreweghe, 'Het prostitutioneel kader te Gent in de periode 1910-1932', Handelingen der maatschappij voor geschiedenis en oudheidkunde te Gent, XLIV (1990) 151-167. Ook in de rest van België werd volgens vele legerartsen tijdens de oorlog de controle op de prostituees opgedreven.

47 Zie J.-R.Leconte Aumôniers militaires belges de la guerre 1914-1918 (Brussel, 1969)64. In Frankrijk kwamen er wel gereglementeerde bordelen in de zone van het front. Dit was niet naar de zin van de Verenigde Staten. Voor de Amerikaanse troepen vormden die bordelen verboden terrein. Ook de Britten waren geen voorstanders van het Franse systeem van prostitutiereglementering. Zie E. H. Beardsley, 'Allied against sin. American and British responses to venereal disease in World War I', Medical history, XX (1976) 189-202; Brandt, No magic bullet, 100-106; M. Harrison, 'The British army and the problem of venereal disease in France and Egypt during the First World War', Medical history, XXXIX (1995) 142146.

48 F. Daels, Voor onze jongens (Leiden, 1918) 12. Over Frans Daels: B. de Wever, 'Daels, Frans', Nieuwe encyclopedie van de Vlaamse beweging, I (Tielt, 1998) 836-839; L. Vandeweyer, 'Frans Daels. Arts bij het ziekbed van zijn volk', in: J. de Maeyer, e. a., ed., Er is leven voor de dood, 265-267.

49 Zie F. Bertrand,La presse francophone de tranchée au front belge, 1914-1918 (Brussel, 1971)78-79; G. Bulthé, De Vlaamse loopgravenpers tijdens de Eerste Wereldoorlog (Brussel, 1971) 57-63, 108. 
begrip voor de beroepsprostituee ging echter gepaard met een totaal nieuw fenomeen van de oorlogsjaren: het afgrijzen van legerartsen voor promiscue meisjes die hun lichaam gratis ter beschikking stelden van de soldaten. Deze meisjes vormden volgens de legerartsen een erg belangrijke besmettingshaard voor de venerische ziekten van militairen. Zij waren - net als de clandestiene prostituees — totaal onwetend op het vlak van geslachtsziekten en stonden niet onder een regelmatige medische controle ${ }^{50}$.

\section{Het reglementarisme in het defensief}

$\mathrm{Na}$ de Eerste Wereldoorlog heerste er in legerkringen regelrechte paniek over het sterk toegenomen aantal venerische ziekten bij soldaten. De legerartsen waren ervan overtuigd dat de meeste soldaten hun geslachtsziekte niet aan het front, maar wel achterin, tijdens de 'verblinding van dronkenmakende verlofdagen' hadden opgelopen. Vele Belgische soldaten brachten tijdens de oorlog hun verlof door in Parijs, dat bekend stond om zijn wufte zeden en door de legerartsen al snel als de belangrijkste infectieplaats voor geslachtsziekten bij soldaten werd beschouwd ${ }^{51}$. 'Paris, centre des congés, a été aussi le grand foyer de la contagion', concludeerde legerarts Wilmaers in $1921^{52}$. Toen vond in Brussel het eerste internationaal congres over militaire geneeskunde en farmacie plaats. Legerartsen bezonnen er zich over de politiek die tijdens de voorbije oorlogsperiode door de verschillende landen met betrekking tot de geslachtsziekten was gevoerd. Het beleid van het Belgisch leger werd op verschillende vlakken ontoereikend bevonden ${ }^{53}$. Ook probeerden legerartsen op dit congres de krijtlijnen voor een nieuwe aanpak van het venerisch probleem bij de strijdmacht uit te tekenen. Het is opvallend hoe weinig aandacht de Belgische legerartsen tijdens dit congres nog hadden voor de prostitutiereglementering. Voortaan zochten zij de oplossing voor het geslachtsziektenprobleem veel meer in individuele profylactische middelen en in seksuele voorlichting van de rekruten.

Ondanks het feit dat de prostitutiereglementering in het Interbellum in België duidelijk

50 Ook na de oorlog bleef de angst voor deze frivole meisjes een belangrijk element in het bestrijdingsdiscours over de geslachtsziekten. Zie bijvoorbeeld D. O. L., Neem uw plaats in! (Brussel, 1948) $42-$ 43. Vg1. Mooij, Geslachtsziekten en besmettingsangst, 122-169.

51 Zie onder andere J. Gaudy, 'Les maladies vénériennes à l'armée', Archives, LXX (juni 1917) 509; B. Dujardin, 'La lutte antivénérienne à l'armée', 4; L. Mélis, Contribution à l'histoire du service de santé à l'armée au cours de la guerre 1914-1918 (Brussel, 1932) 224-226. Zie ook R. Christens, K. de Clercq, Frontleven 14/18. Het dagelijks leven van de Belgische soldaat aan de IJzer (Tielt, 1987) 119.

52 L. Wilmaers, 'Lutte antivénérienne à l'armée', 80. Ook in vredestijd gingen legerartsen ervan uit dat soldaten hun geslachtsziekten vooral tijdens hun verlofperiodes opliepen. Zie bijvoorbeeld Fromont, 'Des moyens de prévenir la propagation de la syphilis dans l'armée, et spécialement dans la garnison d'Anvers. Extrait d'un rapport adressé à M. l'Inspecteur-général du service de santé de l'armée', Archives, XXIII (februari 1872)92.

53 Een vaak geuite kritiek was bijvoorbeeld dat er in België zowel aan het front als achterin een te gering aantal venerologische centra voor soldaten werd opgericht en dat er te weinig uniformiteit bestond in de aanpak van die centra. Over het geslachtsziektenbeleid van het Belgisch leger tijdens de Eerste Wereldoorlog: F. Derbraudrenghien, 'De la conspiration du silence à la propagande. Trente-six ans de lutte antivénérienne à Liège (1912-1948)' (Onuitgegeven licentiaatsverhandeling Université de Liège; Luik, 1998) 36-48. Zie ook J. Gaudy, 'La Guerre et les maladies vénériennes', Le scalpel, LXXII (21 september 1919) 425 . 
aan sympathie en aanhang had ingeboet en dat het toezicht op de uitvoering ervan in vele steden danig was verzwakt, bleef het systeem officieel verder in voege. In de jaren dertig werd in het parlement verschillende keren een wetsvoorstel voor de afschaffing van het reglementarisme ingediend, maar steeds zonder resultaat. De Tweede Wereldoorlog bracht nog een tijdelijke heropleving van het systeem. De Duitsers voerden, net als tijdens de Eerste Wereldoorlog, in de door hen bezette gebieden een strikte vorm van prostitutiereglementering in ${ }^{54}$. Na de Tweede Wereldoorlog ondernam de socialiste Isabelle Blume nog maar eens een poging om officieel een punt te zetten achter meer dan een eeuw reglementarisme. Haar wetsvoorstel werd wel aangenomen; in de zomer van 1948 kwam bij wet een einde aan het systeem. De ontdekking van de penicilline leidde in de daaropvolgende jaren tot een drastische afname van het aantal venerische patiënten.

\section{Legerartsen en het reglementarisme: een balans}

Het is eigenaardig dat legerartsen in de negentiende eeuw zo rotsvast geloofden in het systeem van het reglementarisme. Uit de medische discussies die toen over de geslachtsziekten werden gevoerd, blijkt immers duidelijk dat de diagnose van deze ziekten nog helemaal niet feilloos was. Daardoor is het zeer de vraag of de medische onderzoeken van de prostituees, hoe nauwkeurig ze ook werden uitgevoerd, wel efficiënt konden zijn. Maar misschien waren de steunbetuigingen van de militaire geneeskundigen aan het reglementarisme niet uitsluitend door sanitaire motieven geïnspireerd, zoals sommigen onder hen wel wilden laten uitschijnen en zoals ook vaak in de historiografie wordt gesuggereerd. Wellicht gingen achter hun pleidooien voor de gereglementeerde prostitutie, net als bij vele civiele artsen, ook morele drijfveren schuil. Het onophoudelijk geklaag van de legerartsen over het obsceen gedrag dat prostituees in het openbaar tentoonspreidden, wekt bijvoorbeeld de indruk dat zij de prostitutie niet alleen wilden reglementeren omdat ze een belangrijke infectiehaard voor geslachtsziekten was, maar ook omdat ze in hun ogen een bedreiging vormde voor de publieke moraal. Legerartsen zagen in het reglementarisme, naast een efficiënt systeem om het venerisch probleem bij soldaten te bestrijden, ook een manier om de maatschappij een voortdurende confrontatie met het onbetamelijk gedrag van de publieke vrouwen te besparen. Het reglementarisme moest de prostitutie immers uit het gewone straatbeeld doen verdwijnen en binnen de muren van een aantal weinig zichtbare getolereerde bordelen terugdringen.

Een volledige afschaffing van de prostitutie achtten de meeste legerartsen in de tweede helft van de negentiende en het begin van de twintigste eeuw niet mogelijk en zelfs vanuit moreel standpunt niet wenselijk, want mannen die hun seksuele driften niet op een natuurlijke manier vrij spel konden geven, zochten volgens hen zonder twijfel hun toevlucht in seksuele aberraties. Legerartsen waren grote aanhangers van wat tegenwoordig de leer van de dubbele moraal wordt genoemd, de opvatting dat

54 Voor het geslachtsziektenbeleid van de Duitsers in bezet België: Craps, 'Règlements, législation et contributions médico-sociales belges', 490-493 en F. Derbraudrenghien, 'De la conspiration du silence', 121-125. 
seksuele onthouding wel voor vrouwen, maar niet voor mannen mogelijk is. Het reglementarisme, dat volledig op de leer van de dubbele moraal was gestoeld, wordt daarom dikwijls geïnterpreteerd als een vertaling van de negentiende-eeuwse mysoginie. Ook het feit dat alleen prostituees en niet hun mannelijke klanten aan een vernederend medisch onderzoek werden onderworpen, wordt hiervoor vaak als argument ingeroepen. Maar het leger was (naast de marine) de enige plaats waar ook mannen een medisch onderzoek op geslachtsziekten moesten ondergaan. Soldaten werden geregeld door de militaire artsen op venerische ziekten onderzocht. Voorstellen om alle mannelijke bordeelbezoekers aan zo'n onderzoek te onderwerpen werden echter ook door de meeste legerartsen als volkomen onrealiseerbaar weggelachen ${ }^{55}$.

\section{EEN RADICAAL OFFENSIEF}

Legerartsen waren zelf medeplichtig aan de bedroevende morele reputatie die het leger in de samenleving had. Zij droegen bij tot het beeld van het leger als een oord van obsceen en bandeloos gedrag. Niet alleen benadrukten zij dat de soldaten door hun leeftijd en door de uitzonderlijke omstandigheden waarin zij leefden een risicogroep vormden voor drankmisbruik en venerische ziekten, zij wezen ook voortdurend op de extreme dreiging die de moraal in het leger vanuit twee hoeken ondervond: intern legden de plaatsvervangers een zware hypotheek op het handhaven van de goede zeden, van buiten af ondermijnden de prostituees het moreel niveau van de strijdkrachten.

Maar al hielpen de legerartsen bij het creëren en verspreiden van het sombere beeld van de moraal in het leger, tegelijkertijd zaten zij ook bijzonder verveeld met deze slechte reputatie die hun beroepseer niet bepaald ten goede kwam. In een radicaal offensief tegen drankmisbruik en geslachtsziekten bij soldaten, dat zich niet alleen uitte in een aanhoudende steun aan het reglementarisme maar ook in een reeks verregaande maatregelen binnen het leger zelf, zagen zij een manier om het leger moreel te verheffen. Al beoogden de legerartsen met deze maatregelen zeker ook een verbetering van de salubriteit in de kazerne, daarnaast moesten ze het leger tot een moreel voorbeeld voor de burgerlijke samenleving maken.

De Belgische legerartsen zagen het leger trouwens als een plaats waar de strijd tegen het alcoholisme en de geslachtsziekten het efficiëntst kon verlopen. De discipline en de strikte controle in de kazerne maakten een repressieve aanpak mogelijk. Dit bood volgens de legerartsen ook gunstige perspectieven voor de burgerlijke samenleving. Het leger kon een bron worden van morele regeneratie in een maatschappij die aan drankmisbruik en venerische ziekten ten onder dreigde te gaan. Meynne bijvoorbeeld verwachtte van een alcoholverbod in het leger positieve gevolgen voor de hele samenleving:

55 Niet door Petithan. Die was er wel voorstander van dat alle mannelijke klanten van prostituees aan een medisch onderzoek op geslachtsziekten zouden worden onderworpen. Zie Documents parlementaires. Recueil des pièces, $n r$. 136, séance du 5 avril 1892. Commission chargée, procès-verbaux des séances plénières, 255. 
L'armée poserait ici un exemple de haute moralisation; elle renverrait anuellement dans les rangs de la nation plusieurs milliers de ses enfants qui, pendant leur temps de service, auraient abandonné, d'abord par soumission et plus tard par conviction, cet usage funeste, et qui seraient un enseignement pour leur proches ou leurs voisins ${ }^{56}$.

Legerartsen waren ervan overtuigd dat het kazerneleven niet noodzakelijk tot zedenbederf moest leiden, maar dat het integendeel ook een moraliserende invloed op de soldaten kon hebben. Men moest de weerbare mannen van het land in de kazerne moreel hoogstaand gedrag aanleren, na afloop van hun diensttijd zouden die mannen dat gedrag dan tot voorbeeld stellen van hun familieleden en vrienden. Deze visie op de moreel-opvoedende rol van het leger sloot aan bij de ook buiten België wijd verspreide opvatting dat het leger een leerschool van de natie moest zijn, een plaats waar jongemannen niet alleen goede manieren werden bijgebracht, maar waar zij verder bijvoorbeeld ook leerden lezen en schrijven, waar hun vaderlandsliefde werd versterkt en waar zij zin voor hygiëne, orde, discipline en gehoorzaamheid konden ontwikkelen. 'L'armée doit être une école d'instruction et de moralisation', schreef Auguste Jansen in 1883 in zijn handboek voor militairen ${ }^{57}$. Volgens De Vaucleroy, die hygiëne onderwees aan de militaire school, had de afschaffing van de plaatsvervanging in vele Europese landen het leger al omgevormd tot 'une véritable école d'éducation virile qui fortifie le corps, forme l'intelligence, trempe le caractère, élève le coeur et développe chez lesjeunes citoyens les sentiments du patriotisme ${ }^{158}$.

\section{Meldingsplicht}

In 1842 nam Jean-François Vleminckx als inspecteur-generaal van de gezondheidsdienst van het Belgisch leger de eerste verregaande maatregelen tegen geslachtsziekten bij soldaten ${ }^{59}$. Vleminckx bepaalde dat geen enkele venerische patiënt, hoe licht zijn aandoening ook leek, nog in de kazerne mocht worden behandeld. Elke patiënt die aan een geslachtsziekte leed, moest voortaan naar het hospitaal. Daar zou hij naar de naam en de verblijfplaats worden gevraagd van de publieke vrouw die hem had besmet. Deze gegevens werden doorgespeeld aan de gemeentelijke autoriteiten, in de hoop dat die de nodige maatregelen tegen de betreffende prostituee zouden nemen. Soldaten die weigerden de informatie vrij te geven, moesten worden gestraft, net als diegenen die hun ziekte te lang voor de legerartsen verborgen hadden gehouden. De soldaten die hun ziekte onmiddellijk hadden opgebiecht, moesten daarentegen van elke straf

56 Geciteerd door A. Jansen, 'De l'usage et de l'abus des boissons alcooliques', 560.

57 A. Jansen, Précis d'hygiène (S. 1, 1883) 285. Voor de idee van het leger als morele en intellectuele leerschool van de natie, zie onder andere R. Höhn, Die Armee als Erziehungsschule der Nation. Das Ende einer Idee (Bad Hardzburg, 1963); Wesseling, Soldaat en krijger, F. Snapper, 'Het negentiende-eeuwse Nederlandse leger. Een school der natie?', Mededelingen van de sectie militaire geschiedenis landmachtstaf, Vil ( 1984) 37-56; L. de Vos, 'De Belgische krijgsmacht als natievormende factor, 1830-1885', BTNG, XV (1984) 421-460; W. Klinkert, Het vaderland verdedigd, 356-359.

58 V. de Vaucleroy, De l'alcoolisme dans l'armée, 3.

59 Over Vleminckx: F. de Block, 'Jean-François Vleminckx, patriote de 1830', Archives, LXXV (augustus 1922) 712-743; G. Leboucq, 'Vleminckx (Jean-François)', Biographie nationale, XXIX (1957) 847-849; Evrard, Mathieu, ed., Asklepios onder de wapens, passim. 
en vernedering worden vrijgesteld ${ }^{60}$. Deze maatregelen, die in het leger de verplichte melding van de venerische ziekten invoerden, getuigen overduidelijk van de tendens tot culpabilisering van de prostituee ${ }^{61}$.

De radicale maatregelen van 1842 werden in de daaropvolgende jaren nader gespecificeerd. Op 18 april 1846 werd bij Koninklijk Besluit bepaald dat de venerische patiënten (en de schurftlijders) in de militaire hospitalen recht hadden op dezelfde behandeling als alle andere patiënten. Zij moesten evenveel voedsel en kleding krijgen en konden, indien zij hun ziekte binnen de vier dagen na het verschijnen van de eerste symptomen hadden gemeld, ook aanspraak op een ziekenhuissoldij maken. Vleminckx wilde met dit K. B. een einde maken aan de discriminerende behandeling die syfilitische (en schurftige) soldaten tot dan toe in de militaire hospitalen hadden gekregen en in die zin was het K. B. een belangrijke stap vooruit in de deculpabilisering van de syfilispatiënt (en de schurftlijder). Maar de soldaten die de schaamte voor hun ziekte niet onmiddellijk konden overwinnen, werden door de richtlijn verder in het nauw gedreven. Zij hadden geen enkel recht op een soldij ${ }^{62}$.

Dezelfde tendens ging schuil achter een voorschrift van 25 april 1846 dat een officieel onderscheid invoerde tussen de zogenaamde 'déclarés' — de soldaten die hun ziekte na het verschijnen van de eerste symptomen onmiddellijk hadden gemeld - en de 'non-déclarés' — de soldaten die dat niet hadden gedaan. Op de 'toegangskaan' voor het hospitaal moest worden aangegeven tot welke categorie een soldaat behoorde. De 'déclarés' hadden recht op een behandeling die gelijkwaardig was aan die van de andere patiënten in het ziekenhuis, de 'non-déclarés' daarentegen konden geen aanspraak maken op een soldij en zouden bij hun terugkeer naar het korps worden gestraft 'pour avoir dissimulé leur maladie et l'avoir, par là, volontairement aggravée' ${ }^{63}$.

Legerartsen hadden vastgesteld dat veel soldaten hun geslachtsziekte onverzorgd lieten of de behandeling ervan aan kwakzalvers toevertrouwden om te ontsnappen aan het officieel ingestelde Strafregime dat hen in de militaire hospitalen te wachten stond. Een humanisering van de behandeling van de venerische patiënten moest de soldaten aansporen hun geslachtsziekte niet langer geheim te houden maar ze onmiddellijk aan de legerartsen te melden. De 'non-déclarés' werden uitdrukkelijk

60 'Instruction sur les moyens de prévenir la propagation de la maladie vénénenne', in: Meynne, Recueil des règlements, circulaires, arrêtés, lois et instructions concernant le service de santé de l'armée belge (Brussel, 1844) 318-319. Zie ook J.-R. Marinus, De la prostitution en Belgique (Parijs, 1857) 18. In Frankrijk werden in 1842 soortgelijke maatregelen genomen, maar volgens Quétel werden die van het Belgisch leger veel strikter toegepast. Zie Quétel, Le mal de Naples, 285.

61 In de civiele maatschappij werd heftig gediscussieerd over het al dan niet invoeren van de verplichte melding van geslachtsziekten. Velen achtten zo'n verplichte melding strijdig met het medisch geheim. Toen de Duitsers tijdens de Eerste Wereldoorlog in de door hen bezette delen van België de verplichte melding invoerden, zou dat op heel wat tegenwerking van de Belgische artsen zijn gestuit. Zie Craps, 'Règlements, législation et contributions médico-sociales belges', 485.

62 'Arrêté royal du 18 avril 1846, portant que les militaires atteints de syphilis ou de gale seront traités, dans les hôpitaux, sur le même pied que les autres malades, et qu'ils auront droit à la solde d'hôpital lorsqu'ils auront déclarés spontanément leur maladie des l'apparition des premiers symptômes', JMO (1846)90-91.

63 'Instruction sur l'exécution de l'arrêté du 18 avril 1846, modifiant le régime auquel sont soumis les vénériennes et les galeux traités dans les hôpitaux et les infirmeries', JMO (1846) 91-93. 
uitgesloten van de humanere behandelingswijze. Zij leefden de bestaande richtlijnen niet na en vormden daardoor in de ogen van de legerartsen een enorm gevaar voor de overige soldaten. De legerartsen deden er alles aan om de 'non-déclarés' te stigmatiseren. In 1872 pleitte Fromont in de Archives voor een bikkelharde aanpak van de 'non-déclarés'. Hij wilde bijvoorbeeld dat ze door kwartierarrest van hun vrijheid konden worden beroofd ${ }^{64}$. In 1888 stelde Logie voor om de 'déclarés' verder te deculpabiliseren door ze voortaan als 'blessés' en niet langer meer als 'vénériens' te bestempelen. Maar de 'non-déclarés' mochten van hem zeker niet van dit soort maatregelen profiteren. Zij moesten verder als 'vénériens' worden beschouwd ${ }^{65}$. Legerartsen zagen de 'non-déclarés' als een schandvlek op het leger en ze toonden dan ook geen enkele schijn van mededogen met deze soldaten.

De gezondheidsdienst van het leger creëerde ook geregeld nieuwe redenen om soldaten tot de groep van de 'non-déclarés' te rekenen. Deze categorie van soldaten werd herhaaldelijk opnieuw gedefinieerd. Een omzendbrief van 7 mei 1848 bepaalde bijvoorbeeld dat ook de soldaten die weigerden te onthullen van wie en waar ze hun ziekte hadden opgedaan, voortaan als 'non-déclarés' zouden worden ingeschreven en dus geen soldij meer zouden ontvangen. Wie foutieve of valse verklaringen aflegde over zijn infectiebron, moest door een maatregel van 5 april 1872 ook als 'non-déclaré' worden geregistreerd ${ }^{66}$. Blijkbaar zochten de legerartsen naarstig naar besmette prostituees om ze daarna met de hulp van de gemeentelijke overheden buiten het bereik van de garnizoenen te kunnen plaatsen ${ }^{67}$.

\section{Morele scheidsrechters}

Een snelle behandeling van de besmette soldaten en een efficiënte repressie van de geïnfecteerde prostituees moesten de gezonde soldaten voor geslachtsziekten behoeden. Maar vanuit moreel standpunt was het interessanter om de rekruten te overtuigen van het gevaar van elke vorm van voor- of buitenhuwelijks seksueel contact. Daartoe besloot de minister van oorlog op 30 september 1885 tot de invoering van trimestriële conferenties. De artsen van het leger moesten de soldaten voortaan één keer per trimes-

64 Fromont, 'Des moyens de prévenir la propagation de la syphilis dans l'armée', 91-92.

65 'Seraient donc seuls vénériens, tout court, les non déclarés d'aujourd'hui. Le soidisant stigmate s'appliquerait non pas au mal vénérien mais à la mauvaise action de celui qui enfreindrait les dispositions réglementaires prises dans l'intérêt de tous', stelde Logie voor. Zie Logie, 'De la prostitution', 211.

66 'Circulaire prescrivant quelques dispositions pour arrêter les progrès de la maladie vénérienne dans les rangs de l'armée', JMO (1848) 167-168.

67 In januari 1899 werd echter beslist dat de informatie die soldaten vrijgaven over de publieke vrouw die hen had besmet, niet meer mocht worden doorgegeven aan de gemeentelijke overheden omdat het intieme informatie betrof waarvan de exactheid niet gegarandeerd was. Zie 'Circulaire faisant savoir que la circulaire du 7 mai 1848,6e direction, no. 464, a été abrogée par suite de la mise en vigueur du règlement du ler août 1877',7AfO(1899) 160. Heel wat legerartsen hadden in de enquête van 1888 over het venerisch probleem in het leger al hun twijfel geuit over de efficiëntie van het 'verklikkingssysteem'. Zie bijvoorbeeld Logie, 'De la prostitution', 204 en Spruyt, e. a., 'De la prostitution', 271,284. Toch werd het systeem later opnieuw ingevoerd (zie bijvoorbeeld de circulaire van 7 december 1920), maar in 1921 drong legerarts Lakaye erop aan dat men er weer van zou afstappen omdat het nauwelijks succes oogstte en tot misbruiken leidde: R. Lakaye, 'Lutte antivénérienne à l'armée', in: Congrès international de médecine et de pharmacie militaires au palais mondial du 15 au 20 juillet 1921 (Brussel, 1921) 111. 
ter wijzen op 'les déplorables conséquences de l'inconduite', 'les périls que l'immoralité fait courir à leur santé' ${ }^{68}$. Een primitieve vorm van seksuele voorlichting werd geboren.

Eigenlijk hield Petithan zich al vele jaren vóór de invoering van de verplichte conferenties bezig met de voorlichting van soldaten. Al in 1863 zette hij in de Archives de methode uiteen die hij daarvoor gebruikte:

Je leur racontai l'histoire de l'uréthrite, je leur exposai les agréments des rétrécissements, je les terrifiai par la description de Popthalmie blennorrhagique, je leur donnai une sainte et juste horreur pour le chancre, je les fis trembler à la pensée de la syphilis ${ }^{69}$.

Angst voor de venerische ziekten moest de soldaten aansporen tot respect voor restrictieve seksuele waarden. Petithan vergeleek de rol van de legerarts met die van de goede huisvader ${ }^{70}$.

De voorlichting die Petithan en de andere legerartsen aan de soldaten gaven, was duidelijk eerder van morele dan van medische aard ${ }^{71}$. Volgens Rulot en Sacré wezen de legerartsen de rekruten in hun verplichte conferenties vooral op 'les conséquences déplorables pour l'individu, pour la famille, et pour la société entière, de la débauche, de l'immoralité et des excès de toute manière ${ }^{72}$. De legerartsen gedroegen zich als morele scheidsrechters. De voorlichtingssessies die zij voor de soldaten organiseerden, illustreren nogmaals hoe zij bij hun strijd tegen de venerische ziekten zeker niet louter door sanitaire, maar duidelijk ook door morele motieven werden gedreven, hoe ook zij de angst voor venerische ziekten hebben aangewend om de soldaten tot respect voor het burgerlijk fatsoen te dwingen.

$\mathrm{Na}$ de Eerste Wereldoorlog nam de kritiek op dit soort morele conferenties echter toe $^{73}$. Steeds meer legerartsen stelden zich vragen bij de moraliserende aanpak van de strijd tegen de geslachtsziekten en wilden de klemtoon liever verleggen naar de therapeutische bestrijding ervan. Legerarts Lakaye bijvoorbeeld had een erg beslist standpunt over de efficiëntie van de morele conferenties:

Il est hors de doute pour tous les médecins ayant une certaine pratique militaire, pour tous ceux qui ont été à la guerre, que les conférences morales ont fait faillite. Actuellement encore, certains luttent contre la syphilis en prêchant la chasteté. Allons donc! qu'on laisse

68 'Circulaire indiquant certaines mesures à prendre pour prémunir lesjeunes militaires contre la débauche et ses funestes conséquences', JMO (1885) 416-418.

69 Petithan, 'Note sur le traitement de l'uréthrite', 228.

70 Petithan, 'Prophylaxie des maladies vénériennes', 353.

71 Voor een uitvoerig fragment uit een voorlichtingsconferentie van Peüthan, dat dit bijzonder goed illustreert, zie Documents parlementaires. Recueil des pièces, nr. 136, séance du 5 avril 1892. Commission chargée, procès-verbaux des séances plénières, 205-206.

72 Rulot, Sacré, La vie du soldat belge, 8.

73 Ook in de negentiende eeuw al waren zij niet helemaal onbetwist. Militair arts Célarier stelde in de commissie over de prostitutiekwestie de doelmatigheid van deze morele conferenties openlijk in vraag. Zie Documents parlementaires. Recueil des pièces, nr. 136, séance du 5 avril 1892. Commission chargée, procès-verbaux des séances de la section d'hygiène, 113. 
subsister, pour le bon renom de la morale, ces causeries somnifères, soit, mais disons bien qu'à notre point de vue de médecins de gardiens de la santé physique du soldat elles ne servent à rien et qu'on ne peut lutter contre un instinct aussi primordial, aussi impérieux avec de belles paroles et de sévères recommandations ${ }^{74}$.

Op zieh was Lakaye de idee van seksuele voorlichting nochtans niet ongenegen, maar die voorlichting moest medisch en niet moraliserend van aard zijn. In korte conferenties met filmbeelden moesten de legerartsen de soldaten een beschrijving geven van de verschillende venerische ziekten. Daarnaast moesten ze de militairen wijzen op het bestaan van allerhande profylactische middelen die ter preventie van de geslachtsziekten konden worden aangewend. Hier raakte Lakaye een heikele kwestie. Het gebruik van het condoom en van chemische profylactica als protargol of calomelzalf was in de eerste helft van de twintigste eeuw bijzonder omstreden. Niet alleen werd de werkzaamheid van deze middelen vaak in twijfel getrokken, velen waren er tegen gekant omdat ze tot buitenechtelijke seksualiteit en bordeelbezoek zouden aansporen. Nogal wat legerartsen drongen er echter op aan dat deze middelen in het Belgisch leger ruimer bekend en verspreid zouden raken. Vooral het voorbeeld van het Amerikaans leger, dat tijdens de Eerste Wereldoorlog deze middelen op grote schaal had ingezet en daarmee volgens de legerartsen erg gunstige resultaten had geboekt, werkte inspirerend ${ }^{75}$.

Vele van de vernieuwingen die legerartsen voorstelden, werden in de jaren twintig effectief gerealiseerd: de voorlichtingsconferenties voor soldaten kregen een modernere aankleding, in elke kazerne werden profylactische kamertjes — ruimten waar soldaten na seksueel contact hun geslachtsdelen met allerlei zepen, zalven en andere middeltjes konden reinigen - ingericht en de opsporing van geslachtsziekten bij soldaten werd geoptimaliseerd ${ }^{76}$. De Belgische legerartsen hadden duidelijk lessen getrokken uit de oorlog. Hun vernieuwde aanpak van het geslachtsziektenprobleem oogstte veel lof, niet in het minst van Adrien Bayet, die als hoogleraar van de Université de Bruxelles verbonden was aan de venerologische afdeling van het Brusselse SintPietershospitaal en zich al voor de Eerste Wereldoorlog had ontpopt als één van de heftigste voorstanders van een medische (in de plaats van een moraliserende) aanpak van het venerisch probleem. In de jaren twintig werd een actieplan dat Bayet voor de Hoge Gezondheidsraad had opgesteld de basis van het regeringsbeleid inzake de venerische ziekten. De nadruk lag niet langer op de reglementering van de prostitutie, wel op de oprichting van dispensaria, de gratis ter beschikking stelling van medicatie, een intensieve propaganda bij de bevolking enzovoort. België nam in het Interbellum

74 Lakaye, 'Lutte antivénérienne à l'armée', 108.

75 Zie bijvoorbeeld Gliben, 'La lutte antivénérienne à l'armée belge', in: Congrès international de médecine et de pharmacie militaires au palais mondial du 15 au 20juillet 1921 (Brussel, 1921) 51-54; L. Wilmaers, 'Lutte antivénérienne à l'armée', 82-86. Ook in andere landen bestond er veel discussie over het gebruik van de profylactische middelen. Vgl. B. A. Towers, 'Health education policy 1916-1926: venereal disease and the prophylaxis dilemma', Medical history, XXIV (1980) 70-87; Mooij, Geslachtsziekten en besmettingsangst, 107-116; S. M. Tomkins, 'Palmitate or permanganate. The venereal prophylaxis debate in Britain, 1916-1926*. Medical history, XXXVH (1993) 382-398.

76 Zie Derbraudrenghien, 'De la conspiration du silence', 71-74. 
op het vlak van de geslachtsziektenbestrijding zo'n toonaangevende positie in dat in internationale medische kringen van 'la grande expérience belge' werd gesproken ${ }^{77}$.

\section{Alcoholverbod}

Niet alleen door een krachtdadige bestrijding van het venerisch probleem, maar ook door een radicaal offensief tegen drankmisbruik in de kazerne trachtten de artsen van de Belgische strijdmacht de gezondheidstoestand én de moraal in het leger te bevorderen. Legerartsen plaatsten de maatregelen die tegen alcoholisme bij soldaten werden genomen vaak zelf op één lijn met de richtlijnen die voor de bestrijding van de geslachtsziekten van militairen werden uitgevaardigd. Vanuit de nauwe relatie die zij tussen drankmisbruik en venerische ziekten veronderstelden, namen zij aan dat de strijd tegen het alcoholisme ook de strijd tegen de geslachtsziekten ten goede zou komen.

De meest radicale maatregel tegen drankmisbruik bij soldaten werd op 12 september 1885 afgekondigd. Toen werd een absoluut verbod op alcoholische dranken in de kazerne uitgevaardigd. De invoering van deze maatregel moest gepaard gaan met de installatie van zogenaamde 'mess', kantines waar onderofficieren en soldaten hun vrije uren konden spenderen maar waar uiteraard geen alcohol werd verkocht ${ }^{78}$. Heel lang al hadden bepaalde legerartsen op de invoering van deze maatregel aangedrongen ${ }^{79}$. De tegenstanders van drankgebruik in het leger beweerden dat alcohol erg schadelijk was voor de lichamelijke, morele en intellectuele ontwikkeling van de soldaten. Ook meenden ze dat alcoholmisbruik bij soldaten kon leiden tot ongedisciplineerd, gewelddadig of crimineel gedrag ${ }^{80}$.

Toch waren lang niet alle legerartsen in de tweede helft van de negentiende eeuw te vinden voor een algemeen verbod op alcohol in het leger. Er heerste in de medische kringen van het leger heel wat verdeeldheid over de vraag of geestrijke dranken scha-

77 Over Bayer. M.-T. Nisot, La question eugénique dans les divers pays. Il (Brussel, 1927-1929) 156163; Jacqué, Craps, 'La dermatologie et la syphiligraphie', 244-246; Derbraudrenghien, 'De la conspiration du silence', passim. Voor de lof van Bayet voor de aanpak van het venerisch probleem in het leger, zie bijvoorbeeld A. Bayet, La lutte contre la syphilis en Belgique. Son organisation et ses résultats (Brussel, 1926)12-13,24.

78 'Circulaire interdisant le débit des boissons alcooliques dans les casernes', JMO (1885) 414. Tot de alcoholische dranken werden alleen de gedistilleerde dranken gerekend en niet de gegiste - — zoals bier die in de negentiende eeuw als hygiënische dranken werden beschouwd.

79 Zie bijvoorbeeld A. Meynne, De l'alimentation du soldat (Brussel, 1849). Ook Jansen en Petithan waren overtuigde abolitionisten.

80 Zie bijvoorbeeld de kritiek van Seutin op het hygiënistisch handboek van Marinus: J.-R. Marinus, Essai suri 'hygiène du soldat, 34. Omdat dronken soldaten steeds vaker in ruzies met burgers hun wapens gebruikten, werd in 1862 gedecreteerd dat het voor alle soldaten die in dronken toestand werden gezien voor onbepaalde duur verboden zou worden hun wapens nog buiten de diensturen te dragen. 'Circulaire portant que tout militaire qui aura été vu en état d'ivresse sera privé du port de l'arme pendant un temps indéterminé', JMO (1862) 201. Deze maatregel werd nader gespecificeerd door een aantal andere circulaires, bijvoorbeeld die van 3 april 1871: 'Circulaire portant que la durée de la privation du port de l'arme à infliger aux sous-officiers, ne pourra dépasser trois mois', JMO (1871) 314. In 1874 werd de draagkracht van de maatregel afgezwakt. 'Nouvelles prescriptions relatives à l'interdiction du port de l'arme pour ivresse', JMO (1874) 588). Dit was niet naar de zin van Auguste Jansen. Zie Jansen, 'De l'usage et de l'abus des boissons alcooliques', 564-565. 
delijk, nuttig of noodzakelijk waren voor militairen. Nogal wat legerartsen meenden dat soldaten in de alcohol de noodzakelijke kracht vonden voor hun zware inspanningen of schreven aan alcohol een geneeskrachtige werking toe ${ }^{81}$. De meeste artsen namen een gematigde tussenpositie in. Ze meenden dat beperkt gebruik van alcoholische dranken in het leger wel moest kunnen, maar bepleitten dat dronkenschap hard zou worden bestreden ${ }^{82}$.

$\mathrm{Na} 1885$ klonk er uit de medische kringen van het leger een veel eenstemmiger geluid. De radicale maatregelen die tegen het alcoholisme waren genomen, werden vooral met lofbetuigingen onthaald. Dissidente meningen kwamen bijvoorbeeld in de Archives nauwelijks nog voor. Er werd algemeen aangenomen dat het aantal gevallen van dronkenschap en alcoholisme in het leger door de getroffen maatregelen erg zeldzaam was geworden ${ }^{83}$. Met het oog op een verbetering van de moraal in het leger had de minister van oorlog in november 1886 trouwens nog een belangrijke richtlijn uitgevaardigd om het drankmisbruik bij soldaten terug te dringen. Die richtlijn viseerde - als aanvulling op de maatregel van september 1885 die tegen drankmisbruik in de kazerne was gericht - vooral het onmatig drankgebruik van soldaten buiten de muren van het garnizoen en hield onder meer in dat de namen van de soldaten die voor dronkenschap of openbaar schandaal waren gestraft, op een zichtbare plaats in de kazerne zouden worden opgehangen. Ook werden de legerartsen in de richtlijn opgeroepen om in hun trimestriële conferenties de soldaten voortaan uitdrukkelijk te wijzen op de gevaren van alcoholmisbruik ${ }^{84}$.

Het begin van de twintigste eeuw bracht geen echte wijziging in de houding van de legerartsen tegenover het drankverbod in het leger. De meeste legerartsen bleven het verbod als een goede en noodzakelijke maatregel beschouwen ${ }^{85}$. In november 1914 werd omwille van de oorlogsomstandigheden op het hele Belgische grondgebied dat in handen was van de Belgische en de geallieerde troepen, een verbod op alcoholische dranken ingevoerd ${ }^{86}$. Na de oorlog bestendigde de socialistische minister van justitie Emile Vandervelde deze repressieve aanpak van het alcoholprobleem met een besluitwet (van 15 november 1918) die het produceren, invoeren, vervoeren, verkopen en schenken van sterke dranken, bieren en wijnen met een alcoholgehalte van meer dan $15 \%$ verbood. Onder druk van aanhoudend protest moest Vandervelde deze wet echter

\footnotetext{
81 Zie bijvoorbeeld Jeanty, 'Quelques considérations sur l'emploi de l'alcool dans les affections pulmonaires'. Archives, XXIII (maart 1870) 151-155; Dereine, 'Des usages bienfaisants des boissons alcooliques et des actions physiologiques et thérapeutiques de l'alcool', Archives, XXXV (januari 1882) $5-36$.

82 Zie onder andere $\mathrm{Ch}$. Détienne, Hygiène de l'armée ou préceptes d'hygiène militaire, à l'usage des officiers et des sous-officiers de l'armée (Luik, 1849).

83 Zie bijvoorbeeld V. Desguin, De l'abus des boissons alcooliques. Ses causes, ses résultats, ses remèdes (Antwerpen, Parijs, 1876) 16; E. Dupont, 'Coup d'oeil sur l'hygiène militaire en Belgique depuis 1830', in: H. Kubom, e. a., Aperçu historique sur l'hygiène publique en Belgique depuis 1830 (Brussel, 1897) 255-256; De Broeu, 'Alcoolisme et manie ébrieuse. Responsabilité dans l'ivresse normale et pathologique', Archives, LH (juli 1899)6.

84 'Circulaire prescrivant certaines mesures spéciales contre l'ivrognerie', JMO (1886) 493-495.

85 Zie onder andere Rulot, Sacré, La vie du soldat Belge, 111.

86 'Arrêté royal no. 2421 bisD, du 23 novembre 1914, interdisant l'usage des boissons alcoolisées', JMO (1914) 219-220.
} 
afzwakken. Op 29 augustus 1919 werd een nieuwe wet uitgevaardigd, de zogenaamde Wet Vandervelde. Die verbood de consumptie van alcohol in drankgelegenheden, maar liet wel toe dat thuis alcoholische dranken werden geconsumeerd op voorwaarde dat men minstens twee liter ineens kocht. In de Archives gaven legerartsen hun mening over de Wet Vandervelde niet echt te kennen, maar het valt aan te nemen dat zij, zoals hun collega's in de civiele maatschappij, in overwegend aantal achter deze wet stonden ${ }^{87}$.

\section{IMAGOVORMING}

Niet alleen de radicale maatregelen die in het leger tegen het drankmisbruik werden genomen, maar ook die ter bestrijding van de geslachtsziekten konden in de medische kringen van het leger op veel bijval rekenen. Heel de tweede helft van de negentiende eeuw staken artsen van het Belgisch leger de loftrompet over de maatregelen die Vleminckx en zijn opvolgers tegen de geslachtsziekten bij soldaten hadden genomen ${ }^{88}$. Net zoals de anti-alcoholmaatregelen het drankmisbruik bij soldaten sterk hadden teruggedrongen, hadden volgens hen de maatregelen tegen de venerische ziekten het aantal geslachtsziekten in het leger drastisch verminderd en de secundaire en tertiaire verschijnselen van syfilis in de meeste garnizoenen zelfs helemaal doen verdwijnen.

De legerartsen spraken herhaaldelijk hun trots uit over de manier waarop in het leger de strijd tegen geslachtsziekten en drankmisbruik werd gevoerd. Vooral het venerisch offensief was het paradepaard van de gezondheidsdienst van het leger. De samenleving kon er niet genoeg van worden doordrongen dat het leger op de voorste linie stond in de strijd tegen de geslachtsziekten en aan zijn moreel herstel was begonnen. Het offensief tegen de venerische ziekten in het leger beoogde een verbetering van de gezondheid en de moraal van de soldaten, maar moest ook, net als dat tegen het drankmisbruik, dienen om het imago van de strijdmacht op te poetsen. Legerartsen haalden in hun pleidooien voor de afschaffing van de plaatsvervanging, die zij als een belangrijke oorzaak van drankmisbruik en venerische besmetting in het leger beschouwden, expliciet het argument aan dat deze ingreep het prestige van de strijdmacht ten goede zou komen ${ }^{89}$. En de voorkeur van de legerartsen voor het reglementarisme was zeker ook ingegeven door de wens de (onvermijdbare) illegitieme seksuele contacten van soldaten aan het zicht van de maatschappij te onttrekken en

87 Over deze alcohol wetgeving: B. de Ruyver, 'De alcoholwet Vandervelde in historisch en ideologisch perspectief', Tijdschrift voor sociale wetenschappen, XXVII (1982) 342-369; Scholliers, "Een vijand dien men kennen moet", 149-150.

88 Voorbeelden van deze lofzangen: Binard, 'De la prostitution dans le ville de Berlin et des mesures à prendre pour la combattre ainsi que la syphilis', Archives, III (april 1850) 304, 317; Idem, 'Des maladies vénériennes en Egypte', Archives, VII (maart 1854) 279; A. Jansen, Conférences militaires; entretiens sur l'hygiène militaire (Luik, 1878) 416; L. Mélis, 'Lésions oculaires et cérébrales de cause syphilitique. Observation recueillie à l'hôpital militairede Bruxelles', Archives, XVI (oktober 1879) 299; Umé, 'Névrorétinite syphilitique', Archives, XVII (mei 1880) 293-294; Dupont, 'Coup d'oeil sur l'hygiène militaire', 253-254.

89 Zie bijvoorbeeld 'De la prostitution. (Extraits de rapports)', 349. 
zo een belangrijke oorzaak van de slechte morele reputatie van het leger tot op zekere hoogte te elimineren ${ }^{90}$. In het leger raakten bij de strijd tegen het alcoholisme en de venerische ziekten sanitaire en morele overwegingen verweven met drijfveren als faam en prestige, werd het drank- en het venerisch offensief een instrument voor imagovorming.

Wie niet aan deze imagovorming van het leger meewerkte, haalde zichzelf een hoop ellende op de hals. Meynne bijvoorbeeld raakte hierdoor in het begin van de jaren zestig in een fikse rel met Vleminckx verwikkeld. Vleminckx, die bijzonder zelfvoldaan was over de maatregelen die hij in het leger tegen de geslachtsziekten had genomen $^{91}$, beschuldigde Meynne ervan dat hij aan de Franse arts Jeannel veel te hoge cijfers over het aantal venerische patiënten in de Belgische militaire hospitalen had doorgegeven. Meynne daarentegen beweerde dat hij Jeannel wel correcte gegevens had bezorgd, maar dat die er zelf, in zijn studie over de prostitutie in Bordeaux, foutieve en onverantwoorde bewerkingen had op toegepast. Dit suste Vleminckx allerminst. Vleminckx zag zichzelf als inspecteur-generaal van de gezondheidsdienst van het leger als de enige betrouwbare bron over het aantal venerische patiënten bij soldaten en voelde zich duidelijk voorbijgestoken door Meynne. 'Est-ce que je ne suis pas la seule source officielle en Belgique pour cette espèce de choses? Quelqu'un a-t-il la prétention d'être plus officiel que moi?', schreef hij in het Bulletin van de Koninklijke Academie voor geneeskunde waarvan hij voorzitter was. Vleminckx maakte zich vooral zorgen over het feit dat 'ces fausses appréciations [... ] feront le tour du monde, et la vérité vraie aura bien de la peine à se faire jour'. Toen Meynne met een boze brief reageerde op de verwijten van Vleminckx, liet deze laatste prompt in de Academie een commissie aanstellen om de brief van Meynne te beoordelen. De commissie schaarde zich zoals verwacht achter Vleminckx en bestempelde de brief van Meynne als beledigend en ongepast. Verder heeft Vleminckx naar aanleiding van deze kwestie ook herhaaldelijk bij de minister van oorlog aangedrongen op sancties tegen Meynne. Het kon niet worden geduld dat legerartsen de reputatie van het leger schade toe-

90 Misschien moeten verder ook de richtlijnen die werden uitgevaardigd om de bordelen zoveel mogelijk uit de omgeving van de kazernes te weren niet alleen vanuit sanitair en moreel oogpunt maar ook vanuit dit imagoperspectief worden bekeken. In een circulaire van 30 september 1885 drong de minister van oorlog aan op een betere controle van de 'maisons mal famées qui, véritables parasites, se groupent d'ordinaire autour des quartiers de la troupe', in: 'Circulaire indiquant certaines mesures à prendre pour prémunir les jeunes militaires contre la débauche et ses funestes conséquences', JMO (1885) 416-418. De 'zuiverheid' van de kazerne werd bedreigd door 'parasieten', die blijkbaar onuitroeibaar waren want op 10 maart 1888 volgde opnieuw een maatregel om de bordelen in de buurt van de kazernes te laten verwijderen. 'Circulaire déterminant les mesures à prendre pour prémunir les jeunes militaires contre la débauche et ses funestes conséquences', JMO (1888) 54-55. In maart 1887 was al bepaald dat aan de rekruten de toegang tot bepaalde bordelen en zelfs tot de straten waarin deze etablissementen van verdacht allooi zich bevonden, kon worden ontzegd. 'Circulaire indiquant la marche à suivre lorsqu'il y a lieu d'interdire aux troupes la fréquentation de certains établissements publics', JMO (1887) 40.

91 Vleminckx liet zich bijvoorbeeld in 1849 en in 1862bijzondertriomfantelijkuitoverdespectaculaire resultaten waartoe volgens hem zijn maatregelen tegen de venerische ziekten in het leger hadden geleid. Zie J.-F. Vleminckx, 'De la maladie vénérienne dans l'armée', Archives, II (april 1849) 274-278; Idem, 'Du mal vénérien en Belgique', BARMB, V (1862) 264-290. 
brachten. Er mocht in de samenleving geen twijfel rijzen over het beleid dat Vleminckx in het leger ten aanzien van de geslachtsziekten voerde ${ }^{92}$.

\section{MILITAIRE EN NATIONALE EFFICIËNTIE}

In de tweede helft van de negentiende en het begin van de twintigste eeuw was de idee vrij algemeen aanvaard dat soldaten een risicogroep vormden voor drankmisbruik en geslachtsziekten. In de kazerne werden verregaande maatregelen tegen beide 'plagen' genomen. De vraag of het drankmisbruik en de geslachtsziekten in het leger daadwerkelijk veel dramatischer proporties aannamen dan daarbuiten, is bij gebrek aan betrouwbaar statistisch materiaal moeilijk te beantwoorden. Legerartsen publiceerden - in de geest van de toenmalige statisticomanie - wel regelmatig cijfermateriaal over het aantal alcoholisten of venerische patiënten in het leger, maar dit materiaal was lang niet onbetwist. Dat kon ook moeilijk anders want bijvoorbeeld in de tweede helft van de negentiende eeuw stond de diagnose van de verschillende geslachtsziekten nog helemaal niet op punt ${ }^{93}$. Annet Mooij gelooft alvast niet dat in Nederland de prevalentie van venerische ziekten onder soldaten een voldoende verklaring biedt voor de grote ongerustheid die vooral in het begin van de twintigste eeuw over het geslachtsziektenprobleem in het leger bestond. Immers, ook in voorgaande periodes kwamen geslachtsziekten frequent voor in de strijdmacht en toen lag niemand daar volgens haar echt wakker van. Mooij meent dat die ongerustheid veeleer in verband moet worden gebracht met het toenmalige streven naar national efficiency, naar een weerbare en efficiënt georganiseerde natie. Daar hoorde een goed functionerend leger bij, waarvan de werking niet voortdurend door horden venerische patiënten zou worden verlamd. Terwijl niemand zich voorheen echt had gestoord aan

92 Misschien speelde in deze kwestie mee dat Meynne zich ook al in 1855 behoorlijk sceptisch had uitgelaten over de toestand van de venerische ziekten in het leger. Zie: A. Meynne, 'Mesures prophylactiques contre la syphilis', Archives, VIII (maart 1855) 184-188. Voor het dispuut tussen Vleminckx en Meynne: dossier Antiand Meynne, R. M. 4384, Koninklijk museum van het legeren van krijgsgeschiedenis, Brussel. Zie ook Vleminckx, 'Du mal vénérien en Belgique', 264-290; 'Correspondance', BARMB, V (1862) 298306 en 367-369. Vleminckx is er wel zelf niet in geslaagd zijn optimisme te bewaren. In 1872 liet hij zijn triomfantelijke uitspraken varen en stelde hij voor de Hoge gezondheidsraad een rapport op om bij de overheid aan te dringen op een onderzoek naar het venerisch probleem in België. In dit onderzoek moest er ook specifieke aandacht worden besteed aan de toestand in het leger. Zie: J.-F. Vleminckx, 'Proposition d'enquête sur les ravages des maladies vénériennes', Conseil supérieur d'hygiène publique. Rapports adressés à mm. les ministres de l'intérieur et de lajustice, IV (1867-1873) 475-477. Misschien hield deze omslag in de houding van Vleminckx verband met een rapport dat legerarts Fromont hem had toegestuurd. Fromont dramatiseerde daarin de situatie op het vlak van de geslachtsziekten in het leger en zocht de oorzaak van deze ongunstige toestand vooral in de clandestiene prostitutie. Hij pleitte er uitdrukkelijk voor om voortaan alleen nog meisjes met een certificaat van goede zeden toe te laten in de kazerne. Zie Fromont, 'Des moyens de prévenir la propagation de la syphilis dans l'armée', 84.

93 Wie toch cijfers wil over het aantal geslachtsziekten in het leger, zie bijvoorbeeld Vleminckx, 'Du mal vénérien en Belgique', 264-290; A. Moelier, 'Les maladies vénériennes dans l'armée belge de 1868 à 1886', Uittreksel uit BARMB (Brussel, 1887); J. Gaudy, 'Les maladies vénériennes à l'armée', Archives, LXX (juni 1917) 510; A. Bayet, La lutte contre la syphilis, 35-37. 
een hoog aantal venerische patiënten in de garnizoenen, werd dat nu wel als een levensgrote bedreiging ervaren ${ }^{94}$.

Dit lijkt ook een aannemelijke verklaring voor de panieksfeer die in België in de tweede helft van de negentiende en de eerste helft van de twintigste eeuw bij wijlen, niet alleen over het geslachtsziektenprobleem, maar ook over het alcoholmisbruik in het leger rees. Legerartsen zagen een gedisciplineerd en efficiënt werkend leger als een must om de veiligheid en stabiliteit van het land te garanderen. Drankmisbruik hypothekeerde de noodzakelijke discipline en kon zo het succes van de troepen danig compromitteren. 'Un militaire stupéfié par l'alcool ne pourrait faire une action héroïque, ni rendre les services que la patrie est en droit d'attendre de lui', schreef Auguste Jansen in $1876^{95}$, Daarop somde hij een hele reeks militaire nederlagen op die volgens hem vooral aan het drankmisbruik van soldaten te wijten waren. De verpletterende nederlaag in 1870 van de Fransen tegen de Duitsers bijvoorbeeld schreef hij toe aan het overmatig drankgebruik van een deel van de Franse bevolking, maar vooral ook van bepaalde fracties van het leger:

C'est alors que nous avons vu une partie de la population et quelques indignes débris de l'armée du Rhin en proie à une épidémie alcoolique qui s'est terminée, d'une façon horrible, par l'assassinat des otages et l'incendie de la capitale ${ }^{96}$.

De successen van de troepen van Frederik de Grote in de achttiende eeuw hadden volgens Jansen dan weer alles te maken met de geheelonthouding van deze grote Pruisische vorst ${ }^{97}$. De meeste legerartsen vonden matigheid in het drankgebruik van soldaten cruciaal opdat het leger de veiligheid van het land optimaal zou kunnen garanderen. De Vaucleroy schreef in 1900:

Les autorités militaires ont reconnu, depuis longtemps, que la sobriété est une des conditions fondamentales de la discipline et de la vigueur d'une armée et qu'elle s'impose comme une nécessité à ceux qui ont reçu pour mission d'assurer la sécurité de la patrie ${ }^{98}$.

Over de venerische ziekten in het Belgisch leger bestond een soortgelijk vertoog. Legerarts Jules Gaudy stelde in 1917: 'Au point de vue militaire, le vénérien ne peut produire qu'un rendement médiocre. L'effet déprimant exercé par ce genre d'affection sur le physique comme sur le moral de ceux qui en sont atteints n'est plus à démontrer $^{\prime 99}$. Hoe meer soldaten omwille van een geslachtsziekte in een militair hospitaal

94 Mooij, Geslachtsziekten en besmettingsangst, 105-107.

95 Jansen, 'De l'usage et de l'abus des boissons alcooliques', 5II-5I2.

96 Ibidem, 512. In Frankrijk speelde de zware nederlaag tegen Duitsland in 1870 een beslissende rol in de doorbraak van het anti-alcoholisme. 'Il faut un bouc-émissaire à cette série inexplicable de désastres, un exutoire capable de rassembler une élite désemparée: on trouve l'alcool', schrijft D. Nourrisson in 'Aux origines de l'antialcoolisme'. Histoire, économie et société, VII (1988) 498. Zie ook Nourrisson, Alcoolisme et antialcoolisme en France, 299.

97 Jansen, 'De l'usage et de l'abus des boissons alcooliques', 513-514.

98 De Vaucleroy, De l'alcoolisme dans l'armée, 3.

99 Gaudy, 'Les maladies vénériennes à l'armée', 511. 
moesten worden opgenomen, hoe kleiner het aantal effectief inzetbare soldaten werd en hoe meer de veiligheid van het land in gevaar kwam. Legerartsen berekenden voortdurend de kosten die venerische patiënten en dronkaards voor het leger met zich brachten. Ze telden het aantal rustdagen van deze soldaten en trokken daaruit onrustbarende conclusies over de verspilling van mankracht ten gevolge van alcoholen seksuele uitspattingen.

Het zedeloos gedrag van soldaten werd als een ernstige bedreiging voor de military efficiency gezien, het bevorderen van de moraal in het leger als de beste manier om de discipline te garanderen. Al waren fysiek krachtige soldaten zonder meer een vereiste voor een goed functionerend leger, daarnaast was militaire efficiëntie voor de legerartsen ook sterk gebonden aan een hoogstaande moraal. Soldaten die zich te buiten gingen aan alcohol- en venerische excessen haalden niet alleen de morele reputatie van het leger onderuit, maar ondermijnden ook de slagkracht van de troepen. Moraal, eer en militaire efficiëntie gingen voor de legerartsen hand in hand. Vaak namen zij in hun bijdragen voor de Archives over het alcoholmisbruik of de venerische ziekten van soldaten de gelegenheid te baat om het belang van een gezonde moraal voor het behoud van de discipline in de kazerne te benadrukken. Vooral Petithan liet op dit vlak geen enkele beurt aan zich voorbij gaan. Hij verkondigde herhaaldelijk de idee dat het leger een morele leerschool van de natie moest zijn:

L'armée nationale moderne est essentiellement composée de la partie de la plus virile et la meilleure du peuple. Elle n'est pas seulement l'agent de la force, le soutien de l'autorité, mais encore une véritable école d'éducation. Bonne ou mauvaise, que nous le voulions ou non, elle sera ce que nous la ferons. C'est l'avenir du pays qui est confié à nos mains. Dans notre temps on ne fait plus de la discipline avec la force seulement, la moralité est indispensable ${ }^{100}$.

\section{DE REGENERATIE VAN HET RAS}

Vooral Petithan werd in zijn strijd tegen het alcoholisme en de geslachtsziekten bij soldaten sterk door morele overwegingen gedreven en hij kwam daar ook openlijk voor uit. In de parlementaire commissie over de prostitutiekwestie maakte hij zich zelfs een enkele keer behoorlijk boos op de abolitionisten die hem verweten dat hij in zijn pleidooien voor het reglementarisme geen rekening hield met de moraal. Hij weerlegde dit verwijt door aan de term 'moraal' een ruimere betekenis toe te kennen:

Je proteste contre cette allégation. Seulement, il y a plusieurs interprétations de cette loi morale dans l'ordre relatif où nous vivons. Nous ne méconnaissons pas la morale individuelle, mais nous affirmons l'existence d'une morale nationale. Nous croyons que la visite d'une prostituée est une immoralité infiniment moindre que l'empoissonement de la race ${ }^{101}$.

Petithan toonde zich in zijn bijdragen voor de Archives over alcoholisme en geslachts-

100 Petithan, 'Prophylaxie des maladies vénériennes', 357.

101 Documents parlementaires. Recueil des pièces, $n r$. 136, séance du 5 avril 1892. Commission chargée, procès-verbaux des séances plénières, 207. 
ziekten meermaals erg bezorgd om de toekomst van het ras. In 1863 al achtte hij voorlichtingsconferenties over de geslachtsziekten in het leger gewenst 'pour la beauté et la prospérité de la race humaine'102 en in november 1882 beweerde hij dat het (ondanks de genomen maatregelen) nog altijd hoge aantal geslachtsziekten in het leger ervoor verantwoordelijk was dat 'chaque année l'armée verse dans la nation une cause puissante d'affaiblissement et de dégénérescence de la race ${ }^{103}$.

Als er niet dringend bijkomende maatregelen tegen alcoholisme en venerische ziekten in het leger zouden worden genomen, dan was volgens Petithan het 'Belgische ras' gedoemd te verdwijnen. In 1889 sloeg hij in de Société royale de médecine publique du royaume de Belgique een luide alarmkreet:

150,000 tuberculeux, 100,000 al-coolisés, 50,000 syphilitiques, 50,000 autres affections constitutionnelles sur une popu-lation de 2 millions de citoyens propres à la procréation, voilà l'état de la race à ce point de vue! Et notons que tous ces vices constitutionnels marchent en progression géométrique, car il est peu de ceux qui en sont atteints qui aient l'honnêteté de reculer devant la transmission de leurs maux à leurs descendants. N'ai je pas raison de dire que notre race est profondément malade et qu'il est temps de songer à la guérir $^{104}$ !

Petithan rekende naast het alcoholisme en de geslachtsziekten nog vele andere aandoeningen tot de oorzaken van degeneratie, maar in het leger was zijn aandacht in de eerste plaats op het drank- en het venerisch probleem gericht.

Petithan stond met zijn ideeën over een mogelijke degeneratie van het ras ten gevolge van alcoholisme en geslachtsziekten niet alleen. Vele artsen beschouwden drankmisbruik en venerische ziekten in de tweede helft van de negentiende en in het begin van de twintigste eeuw als belangrijke oorzaken van degeneratie. Hoewel het degeneratiebegrip eigenlijk zijn oorsprong had in de achttiende-eeuwse natuurgeschiedenis, kende het in de tweede helft van de negentiende eeuw door het werk van de Franse psychiater Benedict Augustin Morel een revival in de psychiatrie en de geneeskunde, en later ook in de populaire literatuur. Morel had in 1857 in zijn Traité des dégénérescences physiques, intellectuelles et morales de l'espèce humaine beschreven hoe milieufactoren als voeding en klimaat bij de mens allerhande afwijkingen konden veroorzaken. Die afwijkingen werden erfelijk overgedragen en konden in vier generaties tot steriliteit en uitsterving leiden.

Morel zelf had aan het alcoholisme al een gepriviligeerde plaats onder de oorzaken van degeneratie toegewezen. Valentin Magnan en Paul-Maurice Legrain, twee andere toonaangevende Franse psychiaters, versterkten deze tendens nog. Vooral Legrain, die in 1897 de Union française antialcoolique oprichtte, oriënteerde Morels degeneratietheorie sterk in anti-alcoholische richting ${ }^{105}$. Naast Petithan lieten nog vele

\footnotetext{
102 Petithan, 'Note sur le traitement de l'uréthrite', 229.

103 Petithan, 'Prophylaxie des maladies vénériennes', 352-353.

104 Ch. Petithan, 'La dégénérescence de la race belge, ses causes et ses remèdes', Bulletin de la société royale de médecine publique du royaume de Belgique, VII (september 1889) 66.

105 Over alcoholisme en degeneratie: J. Borel, Du concept de dégénérescence à la notion d'alcoolisme dans la médecine contemporaine. Les campagnes antialcooliques de 1865 à 1965 (Montpellier, 1968); C. Finzen, Der Alkoholismus als Problem der Degeneration um die Jahrhundertwende (Kiel, 1977); F. Bynum,
} 
andere Belgische militaire geneeskundigen zich in het spoor van deze Franse zenuwartsen in verband met alcoholisme tot allerhande minder of meer uitgewerkte doemscenario's verleiden. Zij wezen op de mogelijke fysieke, intellectuele en morele gebreken die de nakomelingen van alcoholici konden vertonen en waarschuwden in het bijzonder voor de dramatische gevolgen van conceptie in dronkenschap voor het nageslacht ${ }^{106}$. Ook probeerden ze de soldaten tot matig drankgebruik of zelfs tot geheelonthouding aan te sporen door hen te wijzen op de relatie die tussen drankmisbruik en waanzin bestond ${ }^{107}$. Verder waren, zoals gezegd, vele legerartsen ook gefascineerd door het verband tussen alcoholisme en crimineel gedrag. De vraag naar de strafrechtelijke verantwoordelijkheid van normale en pathologische dronkaards die in het leger criminele daden hadden gesteld, werd in de Archives meermaals opgeworpen $^{108}$. Vooral in de periode $1880-1914$ dreven legerartsen op alle mogelijke manieren de angst voor de degeneratieve gevolgen van drankmisbruik ten top.

In zijn bijbel van de degeneratie-idee van 1857 rekende Morel de venerische ziekten in tegenstelling tot het alcoholisme duidelijk niet tot de hoofdoorzaken van degeneratie. Het was de Franse veneroloog Alfred Fournier die op het einde van de negentiende eeuw voor het eerst uitdrukkelijk over mogelijke degeneratieprocessen ten gevolge

\footnotetext{
'Alcoholism and degeneration in nineteenth-century European medicine and psychiatry', British journal of addiction, LXX1X (1984) 59-70; Nourrisson, Alcoolisme et antialcoolisme en France, 326-332; J. C. van der Stel, Drinken, drank en dronkenschap. Vijf eeuwen drankbestrijding en alcoholhulpverlening in Nederland (Hilversum, 1995) 199-201. Voorde geschiedenis van het degeneratiebegrip in het algemeen: R. Nye, 'Degeneration and the medical model of cultural crisis in the French Belle Epoque', in: S. Drescher, D. Sabean, A. Sharlin, ed., Political symbolism in modern Europe. Essays in honor of George L. Mosse (New Brunswick, Londen, 1982) 19-41 ; J. E. Chamberlin, S. L. Gilman, ed., Degeneration. The dark side of progress (New York, 1985); D. Pick, Faces of degeneration. A European disorder, c. 1848-1918 (Cambridge, 1989); A. Carol, Histoire de l'eugénisme en France. Les médecins et la procréation XlXeXXe siècle (Parijs, 1995) 87-114. Over het degeneratiedenken in België: G. Bustraen, 'Degeneratiedenken in de Belgische criminele antropologie' (Onuitgegeven licentiaatsverhandeling KU Leuven; Leuven, 1997); L. Beyers, 'Rasdenken tussen geneeskunde en natuurwetenschap. Emile Houzé en de Société d'anthropologie de Bruxelles (1882-1921)', BMGN, CXIV (1999) 481-505.
}

106 Zie bijvoorbeeld V. de Vaucleroy, L'hérédité alcoolique. Conférence faite à l'assemblée générale de la Ligue patriotique contre l'alcoolisme (Brussel, 1893) 11; Lemaire, 'L'Hérédité physiologique et pathologique', Archives, LVII (augustus 1904) 113-114. In enkele studentencursussen die aan de militaire school werden gebruikt, is met betrekking tot het alcoholisme een rudimentaire vorm van de degeneratietheorie terug te vinden. Zie bijvoorbeeld A. de Marneffe, Cours de physiologie et d'hygiène appliquées à l'éducation physique (Brussel, 1904) 174-175, aanwezig in: Fonds Gaston Dothey, 22.5, Koninklijk museum van het leger en van krijgsgeschiedenis, Brussel.

107 Legerartsen stelden niet alleen een correlatie vast tussen een toegenomen alcoholconsumptie en een stijgend aantal krankzinnigen, maar rekenden ook bepaalde vormen van dronkenschap tot de mentale aandoeningen. In de Archives verschenen vaak gedetailleerde observatieverslagen van soldaten die aan delirium tremens, dipsomanie of andere pathologische vormen van dronkenschap leden. Legerartsen testten diverse behandelingswijzen voor deze psychische kwalen uit. Zie bijvoorbeeld Déchange, 'Observation d'alcoolisme sur aigu; mort par hemorrhagic méningée', Archives, XIII (oktober 1860) 234-236; Pirotte, 'Observation de delirium tremens guéri par la teinture de digitale à haute dose', Archives, XVIII (mei 1865) 330-334; Wilmaers, 'Ivresse anormale', Archives, LV (mei 1902) 301-311. Vgl. Nourrisson, Alcoolisme et antialcoolisme en France, 527-544; C. Quétel, J.-Y. Simon, 'L'aliénation alcoolique en France (XIXe et première moitié du XXe siècle)', Histoire, économie et société, VII (1988) 507-533.

108 Zie bijvoorbeeld De Broeu, 'Alcoolisme et manie ébrieuse', 5-22. Zie ook De Vaucleroy, De l'alcoolisme dans l'armée, 4-5. 
van syfilis (en in mindere mate ook gonorroe) sprak. Fournier streefde er vooral naar om met uitvoerige beschrijvingen van de zogenaamde 'hérédo's' — het lichamelijk misvormde en mentaal onderontwikkelde nageslacht van syfilislijders — de angst voor de venerische ziekten op te drijven ${ }^{109}$. Zijn voorbeeld werd door artsen in verschillende landen nagevolgd. In de tweede helft van de negentiende en de eerste helft van de twintigste eeuw verschenen in de medische tijdschriften, ook in de Archives, geregeld gedetailleerde beschrijvingen van de verschrikkelijke ravages die syfilis bij het nageslacht kon aanrichten ${ }^{110}$.

De vrees voor degeneratie ten gevolge van syfilis bracht Fournier er zelfs toe nauwkeurige richtlijnen op te stellen om te bepalen of een huwelijk van een (ex-)syfilispatiënt al dan niet aanvaardbaar was: de patiënt mocht minstens drie à vier jaar geen symptomen van de ziekte meer hebben vertoond en moest een volledige behandeling hebben gevolgd $\mathrm{d}^{111}$. 'La question du mariage des syphilitiques' was op het einde van de negentiende en in het begin van de twintigste eeuw ook een veelbesproken onderwerp in Belgische medische kringen. Legerarts Verhagen bijvoorbeeld stelde in 1907 in de Archives zijn eigen huwelijksrichtlijnen op. Die moesten in radicaliteit zeker niet onderdoen voor die van Fournier ${ }^{112}$.

De stap van dit soort huwelijksvoorschriften naar de eugenetica was niet groot. De angst voor degeneratie ten gevolge van alcoholisme en venerische ziekten speelde een cruciale rol in de eugenetische beweging die op het einde van de negentiende en in het begin van de twintigste eeuw in het spoor van Francis Galton in verschillende landen tot ontwikkeling kwam. De eugenetica bestudeerde de menselijke erfelijkheid met het oog op maatregelen ter verbetering van de kwaliteit van het nageslacht. De kleinschalige eugenetische beweging die België in het Interbellum kende, hield zich ver van de radicale maatregelen (sterilisatie en dies meer) die bijvoorbeeld door Amerikaanse eugenetici voor de preventie van morbide erfelijkheid naar voren werden geschoven. De Belgische eugenetische beweging kan het best als een sociaal-hygiënistische beweging worden getypeerd, die in opvoeding en moralisering veeleer dan

109 Over syfilis en de degeneratie-angst: A. Corbin, 'Le péril vénérien au début du siècle. Prophylaxie sanitaire et prophylaxie morale', in: L. Murard, P. Zylberman, ed., Recherches. L'haleine des faubourgs. Ville, habitat et santé au XIXe siècle (Fontenay-sous-Bois, 1978) 283. Zie ook de al genoemde algemene werken over het degeneratiebegrip.

110 De erfelijkheid van syfilis werd, naast de besmettelijkheid van de ziekte, in de tweede helft van de negentiende en de eerste helft van de twintigste eeuw vrij algemeen aangenomen. Er bestond wel onenigheid over de vraag of alleen de vader, alleen de moeder of beiden hierin een aandeel konden hebben. Ook bleef lange tijd onduidelijk op welke manier die overdracht precies verliep. Legerarts Delforge beschreef in de Archives bijvoorbeeld een geval van erfelijke syfilis dat volgens hem louter aan 'l'hérédité paternelle' te wijten was. De moeder van het kind met erfelijke syfilis vertoonde — aldus Delforge — nooit enig symptoom van de ziekte. Delforge, 'A propos d'un cas de syphilis héréditaire', Archives, XLI (mei 1888) 319-325. Over de negentiende- en vroeg-twintigste-eeuwse opvattingen over de erfelijkheid van syfilis: E. Lomax, 'Infantile Syphilis as an exemple of nineteenth century belief in the inheritance of acquired characteristics', Journal of the history of medicine and allied sciences, XXXIV (januari 1979) 23-39; A. Corbin, 'L'hérédosyphilis ou l'impossible rédemption. Contribution à l'histoire de l'hérédité morbide', Romantisme. Revue du dix-neuvième siècle, XI (1981) 131-149.

111 A. Fournier, Syphilis et mariage (Parijs, 1880). Zie ook Quétel, La mal de Naples, 186-198; Carol, Histoire de l'eugénisme, 51-61.

112 Verhagen, 'Du traitement de la syphilis', Archives, LX (maart 1907) 168. 
in dwang een oplossing zocht voor onder meer het drank- en het venerisch probleem. Legerarts Albert Govaerts, als secretaris-generaal van de Société belge d'eugénique één van de actiefste propagandisten van de eugenetica in België, maakte het eugenetisch gedachtegoed via de Archives bij zijn collega's legerartsen bekend. Hij trachtte hen ervan te overtuigen dat de eugenetica de militaire geneeskunde erg tot nut kon zijn, bijvoorbeeld bij de rekrutering voor het leger. Govaerts kon alvast rekenen op de steun van de toenmalige inspecteur-generaal van de gezondheidsdienst van het leger Léon Wilmaers. Die gaf in zijn voordrachten en geschriften over de strijd tegen de venerische ziekten in het leger blijk van een grote bekommernis om de kwaliteit van het ras en wees in de Journées internationales d'eugénique van oktober 1922 op de bijdrage die de gezondheidsdienst van het leger, bijvoorbeeld met haar antropometrisch onderzoek van soldaten, aan de eugenetica kon leveren ${ }^{113}$.

In de tweede helft van de negentiende en het begin van de twintigste eeuw toonden de legerartsen zich in hun vertoog over drankmisbruik en venerische ziekten bij soldaten in toenemende mate bezorgd om de toekomst van het ras. Een fysiek verzwakt en moreel verdorven leger zagen zij als symptomatisch voor een nakende degeneratie van de hele maatschappij. Het leger was voor hen een index, een maatstaf van de nationale vitaliteit. Een regeneratie van het ras kon volgens hen alleen maar in het leger beginnen. Een offensief tegen drankmisbruik en venerische ziekten bij soldaten moest het leger moreel verheffen en omvormen tot 'la grande école nationale'. Voortaan moesten soldaten het leger als herboren verlaten: 'Il faut qu'à l'expiration de leur service, les miliciens soient rendus en leurs foyers moralement et physiquement améliorés ${ }^{114}$. Zo zouden de in het leger genomen maatregelen tegen alcoholisme en geslachtsziekten ook op de civiele maatschappij een heilzame uitwerking kennen. Legerartsen beschouwden het leger als de voornaamste waarborg voor de fysieke en morele gezondheid van de natie:

Officiers et médecins militaires doivent comprendre que le pays favorisera d'autant plus l'armée qu'elle donnera plus de gages de moralité. Telle sera l'armée, telle sera la nation! Tâchons donc, par tous les moyens, d'avoir une armée saine, morale, énergique, pour avoir une Race semblable ${ }^{115}$.

113 Zie A. Govaerts: 'L'Eugénique', Archives, LXXIV (december 1922) 1201-1221. Voor Wilmaers: Wilmaers, 'Lutte antivénérienne à l'armée, 77-95; A. Govaerts, 'Journées internationales d'eugénique', Archives, LXXIV (december 1922) 1271-1274. Voor de eugenetica: D. J. Kevies, In the name of eugenics. Genetics and the uses of human heredity (Harmondswoith, 1986); W. Schneider, Quality and quantity. Eugenics and the biological regeneration of twentieth century France (Cambridge, 1987); J. Noordman, Om de kwaliteit van het nageslacht. Eugenelika in Nederland(1900-1950) (Nijmegen, 1989); W. de Raes, 'Eugenetika in de Belgische medische wereld tijdens het Interbellum', BTNG, XX (1989) 399-464; P. Weindling, Health, race and german politics between national unification and nazism, 1870-1945 (Cambridge, 1989); R. A. Soloway, Demography and degeneration. Eugenics and the declining birthrate in twentieth-century Britain (Chapel Hill, Londen, 1990); Carol, Histoire de l'eugénisme; J.-F. Crombois, 'De eugenetica in België vóór 1914. Het Institut de sociologie Solvay (1902-1914)', in: M. Beyen, G. Vanpaemel, ed., Rasechte wetenschap? Het rasbegrip tussen wetenschap en politiek vóór de Tweede Wereldoorlog (Leuven, Amersfoort, 1998) 31-41.

114 'Circulaire interdisant le débit des boissons alcooliques dans les casernes', JMO (1885) 416.

115 Petithan, 'La dégénérescence de la race belge', 75. 


\section{ALGEMEEN}

E. C. Coppens, ed., Honoris causa. Opstellen aangeboden aan prof. mr. O. Moorman van Kappen ter gelegenheid van zijn vijfentwintigjarig jubileum als hoogleraar aan de Faculteit der rechtsgeleerdheid van de Katholieke universiteit Nijmegen (Rechtshistorische reeks van het Gerard Noodt instituut XLII; Nijmegen: GNI, 1999, ix + 105 blz., ISBN 907147860 2).

Sinds zijn benoeming, in 1971, tot hoogleraar in de Nederlandse rechtsgeschiedenis heeft Moorman van Kappen zich met veel energie en eruditie ingezet voor de beoefening van de rechtshistorie. Een van de resultaten der daarbij behorende taken, de begeleiding van promovendi, werd in 1996 gepresenteerd op een klein symposium. Zes promoti van Van Kappen hielden bij dat huldebetoon voordrachten die nu, eindelijk, zijn gebundeld. De bijdragen weerspiegelen voor een deel de terreinen die de leermeester zelf toegankelijk heeft helpen maken, met name de (inter)regionale rechtsgeschiedenis van 'Limburg' en de praktijk en codificatie van het (straf)procesrecht.

A. M. J. A. Berkvens biedt in zijn verhandeling over 'Het nieuwe landrecht van Thorn. Verlicht absolutisme en codificatie onder het bewind van vorstin-abdis Maria Cunegonda van Saksen (1776-1794)' (1-28) een boeiende kijk op de wonderlijke verwikkelingen waartoe de gecompliceerde gezagsverhoudingen in het verbrokkelde Overkwartier van Gelre konden leiden als een goedwillende vorstin niet voldoende rugdekking van adel en burgers wist te verkrijgen voor haar pogingen een meer zeitgemass wetboek annex rechterlijke organisatie te creëren. De tijd heeft behoudende particularisten en 'progressieve' vorstin hardhandig ingehaald. In zijn bijdrage 'Visis actis' presenteert A. Fl. Gehlen zijn 'Eerste bevindingen bij de openlegging van het gerechtelijke archief der Luikse commissarissen-deciseurs te Maastricht (1632-1794)' (4960). Het betreft hier ruim driehonderd nu (pas) toegankelijk gemaakte procesdossiers en vonnissenboeken. Een nieuw veld voor onderzoek ligt open. G. H. A. Venner beschrijft de resultaten van een thematisch rechtspraakonderzoek in 'Van trouwbeloften en soevereiniteit. Ingrijpen van de Staten-Generaal in de rechtspraak van het Hof van Gelder te Venlo (1717-1795)' (7591). Het gaat om de juridische steekspelen en staatkundige repercussies (wegens evocatie) in de casus van de trouwbeloften gesloten tussen de in 1730 amper veertienjarige Catharina Hester in de Betouw en de advocaat Paulus van Darth, 36 jaar oud, welke sponsalia door de vader van het meisje, Arnold in de Betouw, in rechte werden aangevochten — uiteindelijk, in 1734, met succes.

Onder de bescheiden titel 'Enige aantekeningen over het Utrechts burgerrecht' (29-47) geeft $\mathrm{M}$. W. van Boven een breder zicht op dit oude fenomeen dat jammer genoeg nog maar weinig bestudeerd is. De recente botsingen tussen rechter en administratie hebben hun wortels mede in het wettelijke toetsingsrecht dat onze bestuurderen boven het hoofd hangt. L. M. Koenraad gaat op de historische dimensie in, onder een titel die een knipoog naar de actualiteit bevat: 'De rechter als burgemeester. De verhouding tussen rechterlijke macht en het bestuur historisch bezien' (61-74). A. J. van Weel tenslotte bestudeerde een soort rechtspraak, namelijk van Gedeputeerde Staten, die men sindsdien als een anomalie is gaan zien: 'De strafrechtspleging in eerste aanleg door de Gecommitteerde Raden van Holland en West-Friesland in het Zuiderkwartier (1723-1795)' (93-105). Het gaat hier om 176 vonnissen, waarvan 88 bij verstek, gewezen in zaken als ambtsdelicten, bedreiging van belastingfunctionarissen, aantasting van de in- en uitwendige veiligheid van het gewest Holland, en valsemunterij.

De auteurs zijn schatplichtig aan hun leermeester wiens 'open buydel', hen in 1973 bij 